\title{
Gestión y planificación ambiental y territorial en Calvià
}

\section{Environmental and territorial management and planning in Calvià}

\author{
Álvaro Sánchez Robles \\ alvarosanrob@gmail.com \\ Université Paul-Valéry Montepellier 3
}

\begin{abstract}
The great development Majorca suffered in the 20th century especially affected Calvià, whose growth in the last century has brought enormous consequences. This article assesses the municipality's commitment to the environment, finds out if it is heading for the best possible scenario or not, and studies its political action. In addition, an environmental benchmarking is carried out between the Calvià initiatives and those proposed by the Urban Agenda for the EU and La Palma and Culatra Island. Finally, the proposals that could lead the municipality to improve the current situation are highlighted.
\end{abstract}

Key words: benchmarking; ambitious; zero emissions; commitment; greenwashing.

\section{Resumen}

El gran desarrollo que sufrió Mallorca en el siglo XX afectó especialmente a Calvià, cuyo crecimiento en el último siglo le ha traído enormes consecuencias. Este artículo evalúa el compromiso del municipio con el medio ambiente, averigua si se encamina al mejor escenario posible o no y estudia su acción política. Además, se realiza un benchmarking 
medioambiental entre las iniciativas de Calvià y las propuestas por la Agenda Urbana de la UE y La Palma y la isla de Culatra. Por último, se destacan las propuestas que podrían llevar al municipio a mejorar la situación actual.

Palabras clave: benchmarking; ambicioso; cero emisiones; compromiso; greenwashing.

\section{Introduction}

Nowadays Calvià is the second municipality with highest population in Mallorca, with 50.559 inhabitants, behind Palma and the most touristic one with more than one and a half million tourists per year (Institut d'Estadística de les Illes Balears, s.f.). But it was not always in this way. In order to understand the actual situation, it is essential to have a look into the background of the municipality. At the beginning of the XX Century, Calvià's main activity was the agriculture and the population were around 2.500 inhabitants. It was in the 60's when tourism started to grow jumping from 6.800 seats to 120.000 in 1997. In response to these changes in the municipality appeared the Calvià Agenda Local 21 (Prats, 1997) in the year 1997, which described the tourism development as improvised, with a short-term vision, based on an unlimited growing real estate and the unsustainable exploitation of the natural resources.

Pushed by the Calvià Agenda Local 21, it was created a new General Urban Planning Plan in the year 2000 (PGOU 2000) (Dañobeitia, 2000), which contained the objectives and aspirations of the agenda. In the year 2006 there was a modification of it, which will be named from now on as MPGOU 2000 (Dañobeitia, 2006). It was strongly focused on the territorial planning, following the guidelines of the Agenda Local 21. Five years later, in 2011, Calvià joined the Covenant of Mayors, committing itself to implement the EU's climate and energy objectives, which meant a CO2 reduction of 20\% by the year 2020 .

Finally, there is an Advance of the PGOU in the year 2017 (Carbonero, 2017) (APGOU 2017 from now on) which proposes certain updated measures and objectives in order to address the current issues of the municipality.

With this whole situation there are two research questions that guide this article: 
- Is there an actual commitment of the municipal council to the environment? And if it is the case, is it doing its best?

- Where should it head from now on?

\section{Methodology}

The article will be based on bibliographic information. Firstly, the section of "Results" will describe the situation of Calvià in the last twenty years according to three different scopes: territorial planning, transport and resources. Each of them will be described relying on the information provided by the Agenda Local 21 of Calvià, the MPGOU2000 and the APGOU2017. In addition, the energy consumption section will use the information of the documents agreed in the Covenant of Mayors in one of its points and the same will be done in the water consumption and waste generation with the data of Calvià 2000 S.A. Secondly, the comparative study will be based on two pillars. The first one is the Urban Agenda for the $E U$ and its respective action plans. The second one will give two examples of urban areas committed with the environment thanks to the Clean Energy for EU islands initiative.

The article will be divided in two parts: results and comparative study. The results will describe five different topics following the same structure. These are the territorial planning, the transport, the energy consumption, the water consumption and the waste management. The structure will be the following: (1) a table where the main goals and initiatives will be shown; (2) each of them will be divided in three or four sections according to the main source of information; the main ones are Agenda 21, MPGOU2000 and APGOU2017; (3) some conclusions of the performance of the municipality in this topic.

The comparative study will introduce in the first place the Urban Agenda for the EU and lately will go deepen in its four action plans, which are: The Climate Adaptation Partnership (European Commission, 2018), the Circular Economy (European Commission, 2018), the Energy Transition (European Commission, 2019), and the Partnership for Urban Mobility (European Commission, 2018). Secondly, it will be explained what the Clean Energy for the $\mathrm{EU}$ islands is and later two cases of islands which joint this initiative, La Palma (European Commission, 2019) and Culatra (European Commission, 2019). Finally, there will be a 
discussion where the solutions proposed in the comparative study will try to match with the issues described in the results section.

The last part of the article will be composed by some final conclusions in which the performance of Calvià municipality in the last twenty years will be reviewed and the research questions will try to be answered. (Barcik, s.f.)

\section{Results}

The following results are divided into territorial planning, transport, energy, water and waste and aim to answer both research questions.

\subsection{Territorial planning}

Agenda Local 21

Goals: reduction of $1348 \mathrm{Ha}$ of developable land

Initiative: five years moratorium in significant coastal constructions and implement the declassification developable land in the PGOU 2000

The main goal described in the Agenda Local 21 of Calvià was for the PGOU to keep the declassification of 1348 has of developable land in order to ensure the sustainability of the municipality through the PGOU and it proposed a five years moratorium in the significant constructions on the coast.

In Figures 1 and 2 we can see the evolution of the urban development in Calvià since the year 1991 to 2009. The starting point in the year 1991 was $2396 \mathrm{Ha}$ of urban land which was slightly reduced in the year 2000 to $2372 \mathrm{Ha}$. However, the rural land changed abruptly, from $10240 \mathrm{Ha}$ in 1991 to $11981 \mathrm{Ha}$ in 2000. The reason for this fast retreat was the Agenda Local 21 , which set up the goal of a reduction in the developable land of $1350 \mathrm{Ha}$ and asked to implement it in the PGOU 2000. The figure shows this drop of the developable land from $1736 \mathrm{Ha}(455+76+1205 \mathrm{Ha})$ in 1991 to $19 \mathrm{Ha}$ in 2000 . 
Figure 1. Territorial planning. Calvià 1991-2000
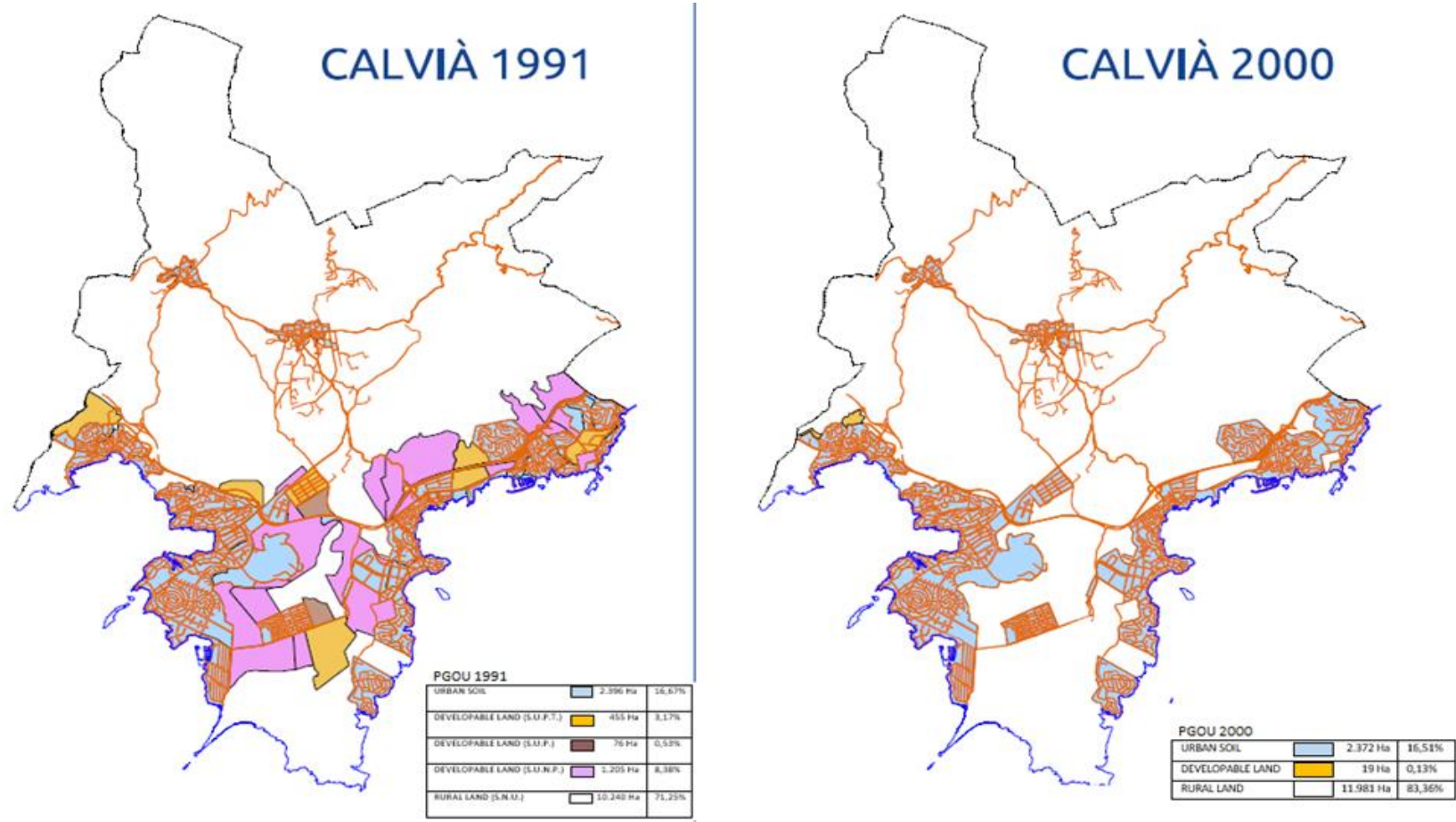

Source: www.calvia.com

The difference between the years 2000 and 2009 is not so remarkable. The urban soil is exactly the same, and the rural land has decreased in the 2009 by $57 \mathrm{Ha}$ as a result of the rise of the developable land from $19 \mathrm{Ha}$ to $76 \mathrm{Ha}$. 
Figura 2. Territorial planning Calvià
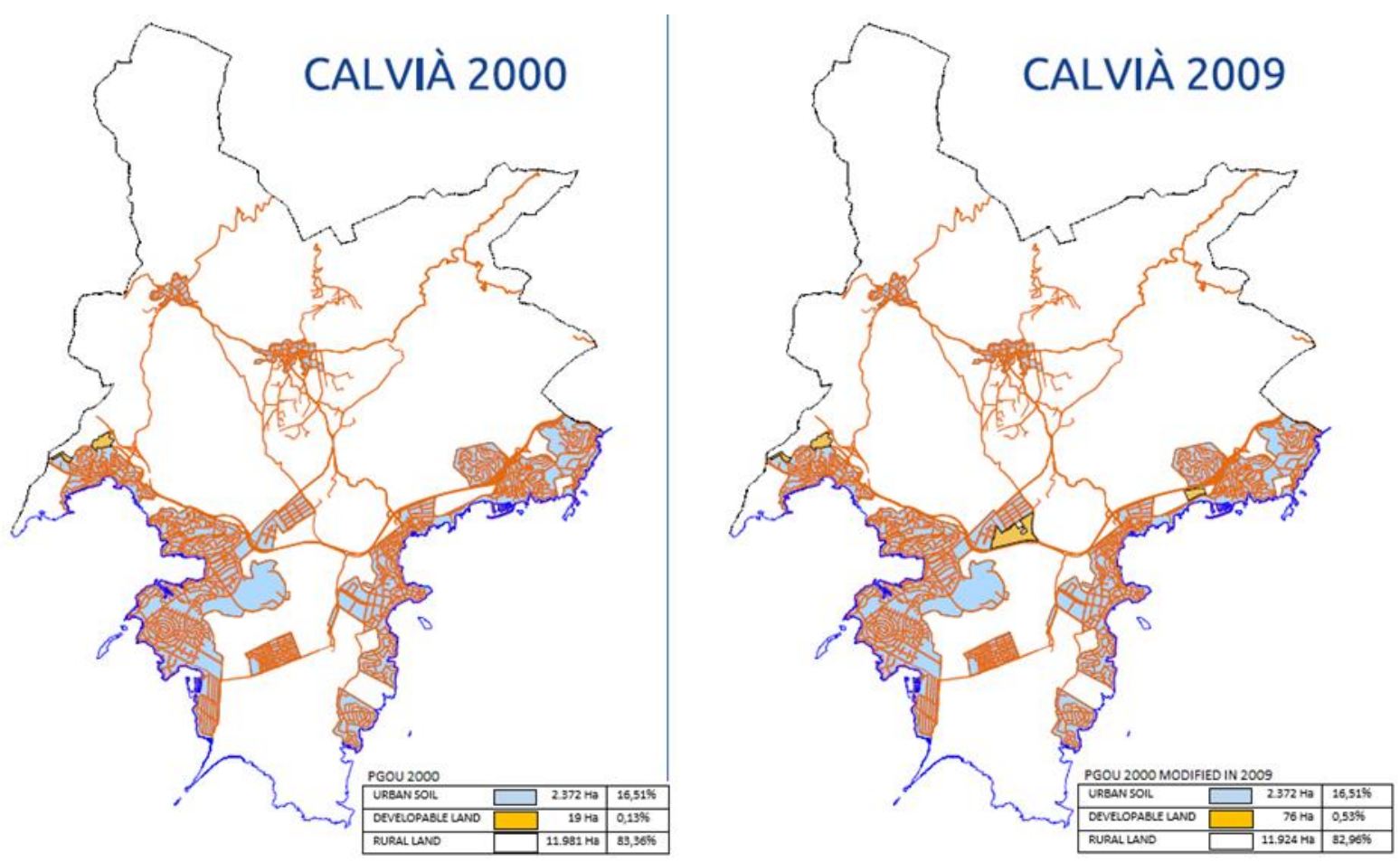

Source: www.calvia.com. Ayuntament de Calvià, s.f.

MPGOU 2000

Goal: reduction of urban development land and the comprehensive rehabilitation of the coastal space

Initiative: declassification of 1348 hectares and esponjamiento ${ }^{1}$

APGOU 2017

Goal: giving a better use to the developable land than the current one and potential future projects

${ }^{1}$ Activity which consists in the wrecking of an obsolete building in order to create an area of public interest. 
Initiative: Ecobarri Son Bugadelles, Dry marine Son Bugadelles, Natural Park Magaluf marine, Ses Planes triangle and some other projects

Some of the most significant actions included in APGOU 2017 are located in Figure 3 and later described one by one:

\section{Figura 3. Territorial planning. Map of Apgou 2017 actions}

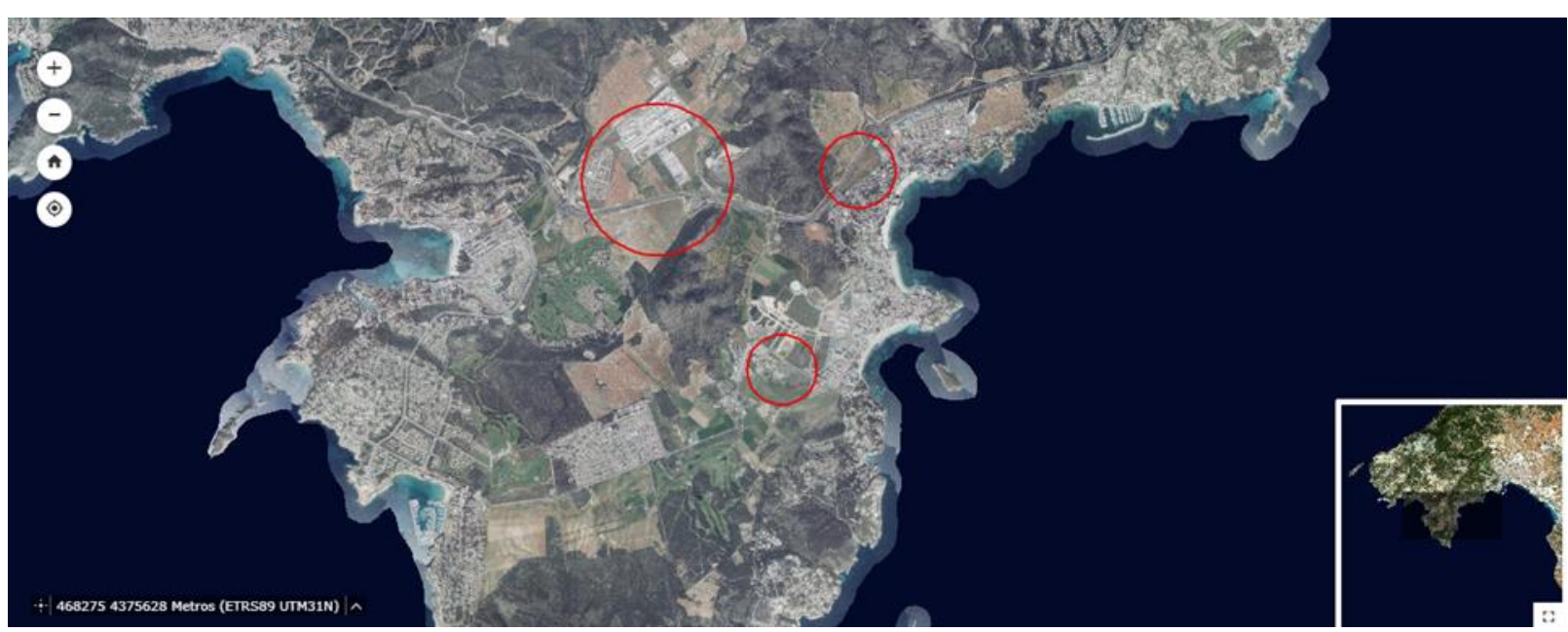

Source: IDEIB, s.f.

- EcobarriSon Bugadelles: the construction of an environmentally friendly residential area in Son Bugadelles which appears in Figure 4. 
Figura 4. Territorial planning. Ecobarri Son Bugadelles

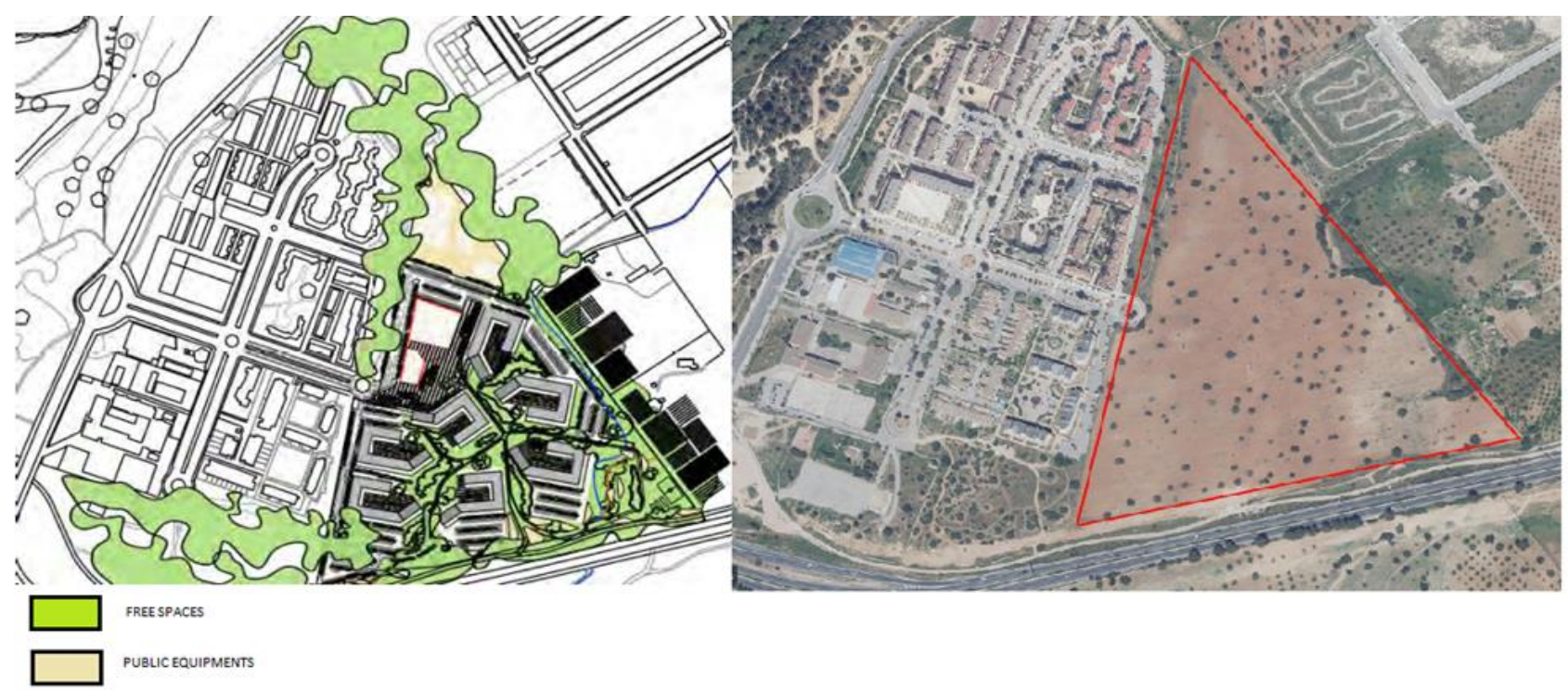

Source: APGOU 2017 and IDEIB, s.f.

- Dry marine of Son Bugadelles: APGOU 2017 proposes the construction of a dry marine in a developable land area in the industrial estate of Son Bugadelles, in the area shown in Figure 5.

\section{Figura 5. Territorial planning. Dry Marine Son Bugadelles}

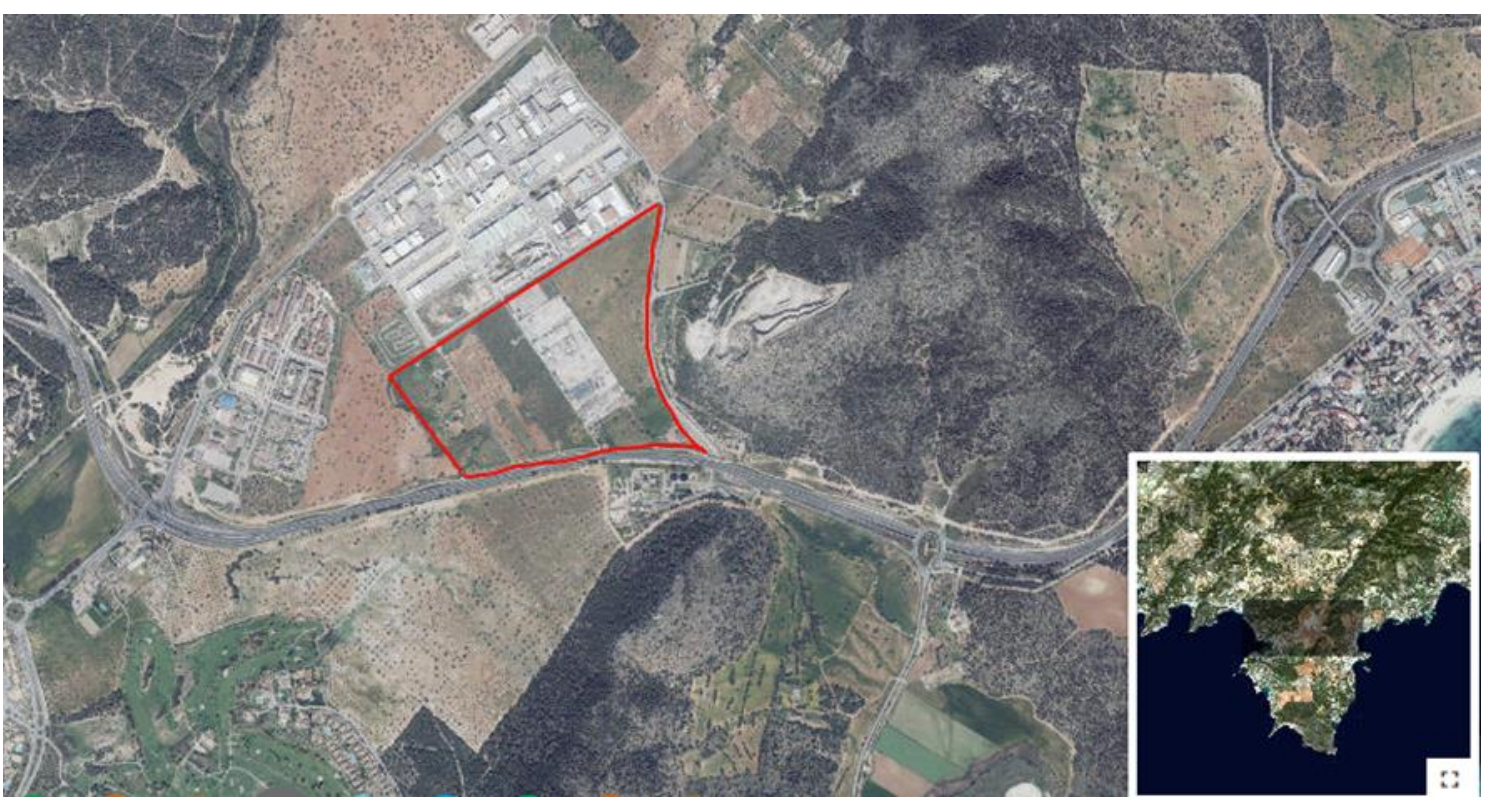

Source: IDEIB, s.f. 
- Natural Park Magaluf marine: the creation of a natural park in an area that contains rural land and false urban land.

In Figure 6, we can see the above explained Natural Park Magaluf marine, in the area contained into the read lines, which will be composed by a new lamination raft.

\section{Figura 6. Territorial planning. Natural Park Magaluf Marine Currently}

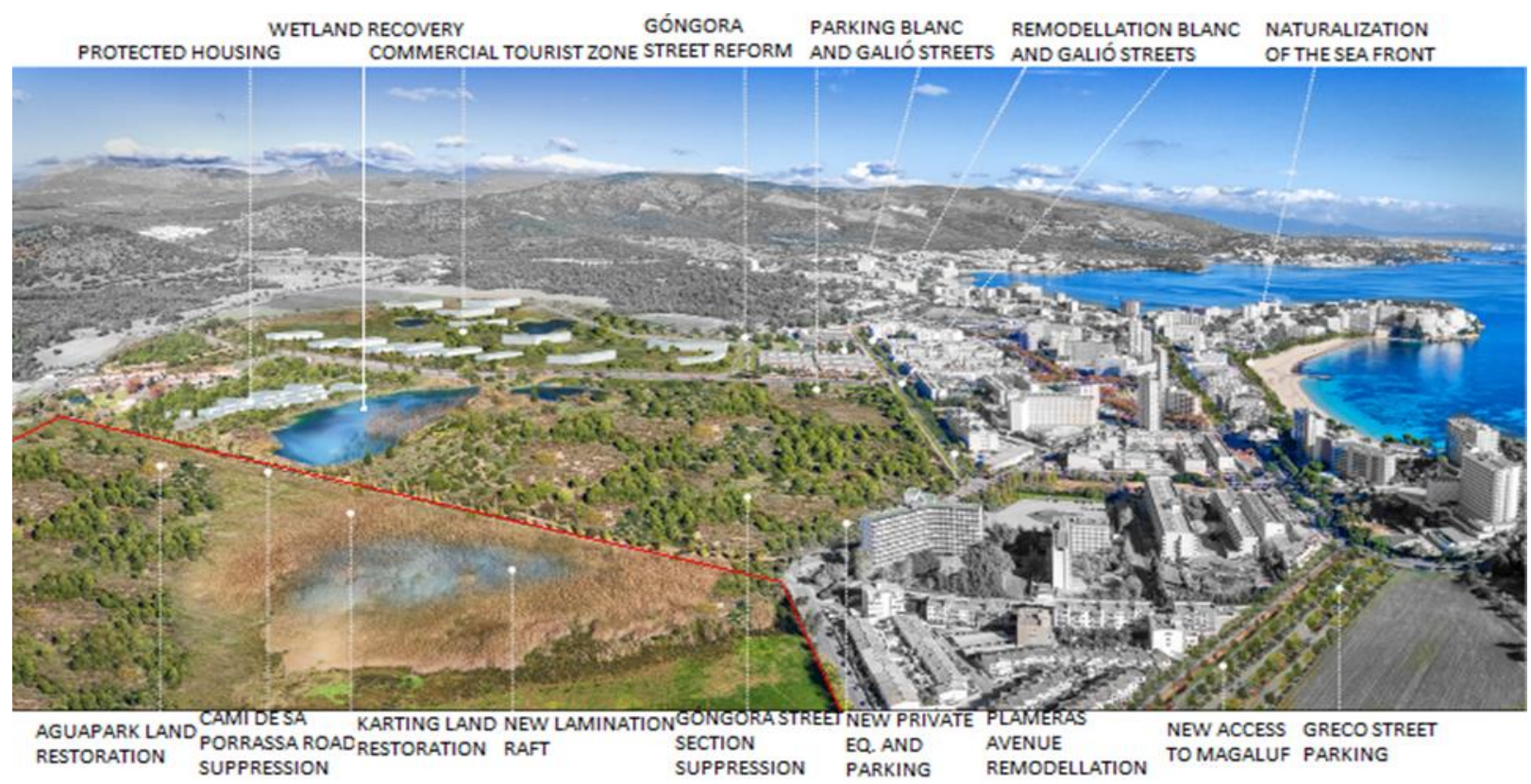

Source: APGOU 2017

\section{Figura 7. Territorial planning. Natural Park Magaluf Marine Project}

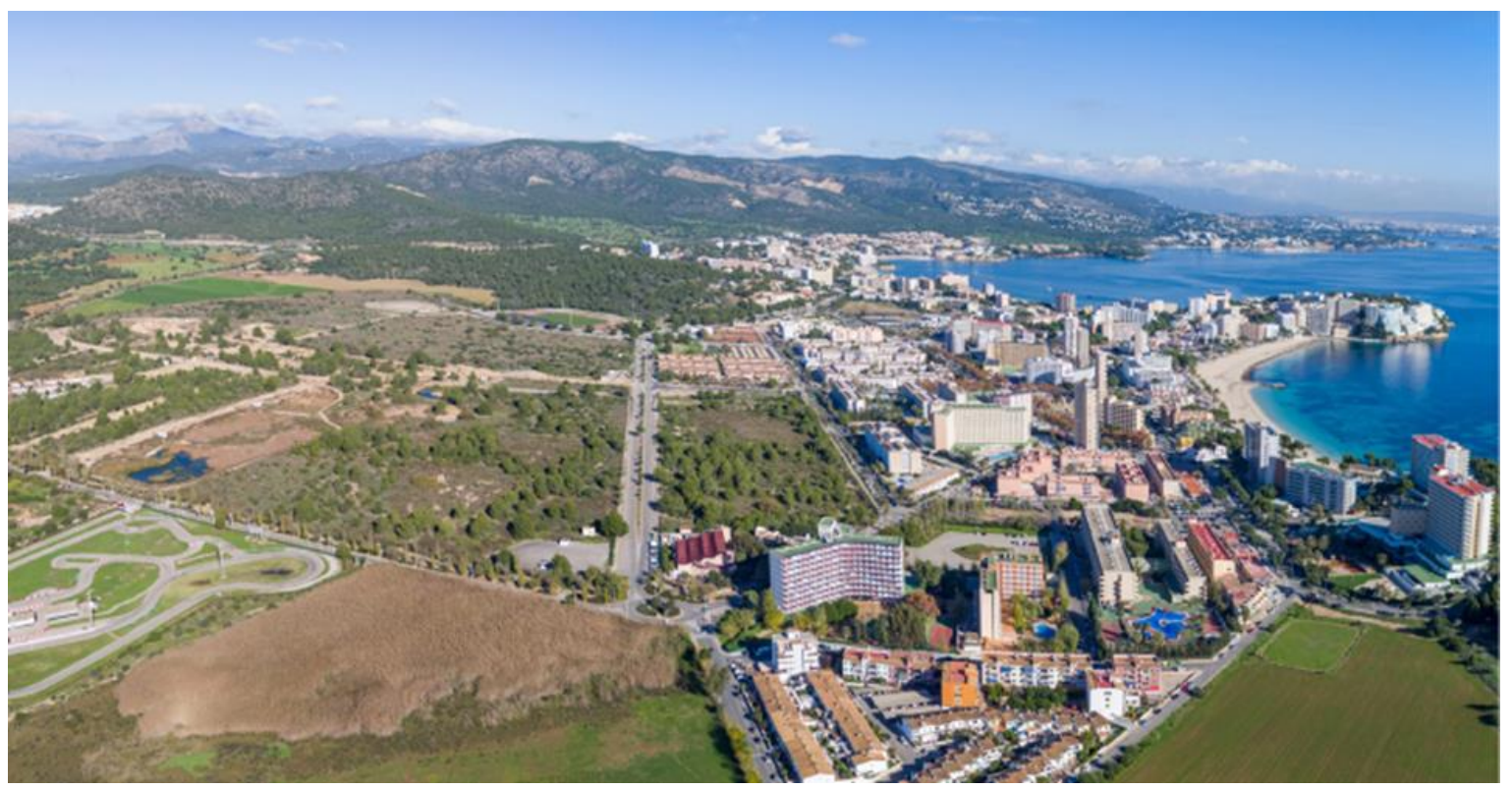

Source: APGOU 2017 
- Ses Planes triangle: the deployment of community and commercial equipment. The current situation appears in the figure 8 while the one with the project performed in the figure 9.

The area of Ses Planes triangle was rural land until the modification of PGOU in 2013, nowadays it is considered developable land directly ordered.

Figura 8. Territorial planning. SES Planes Triangle Currently

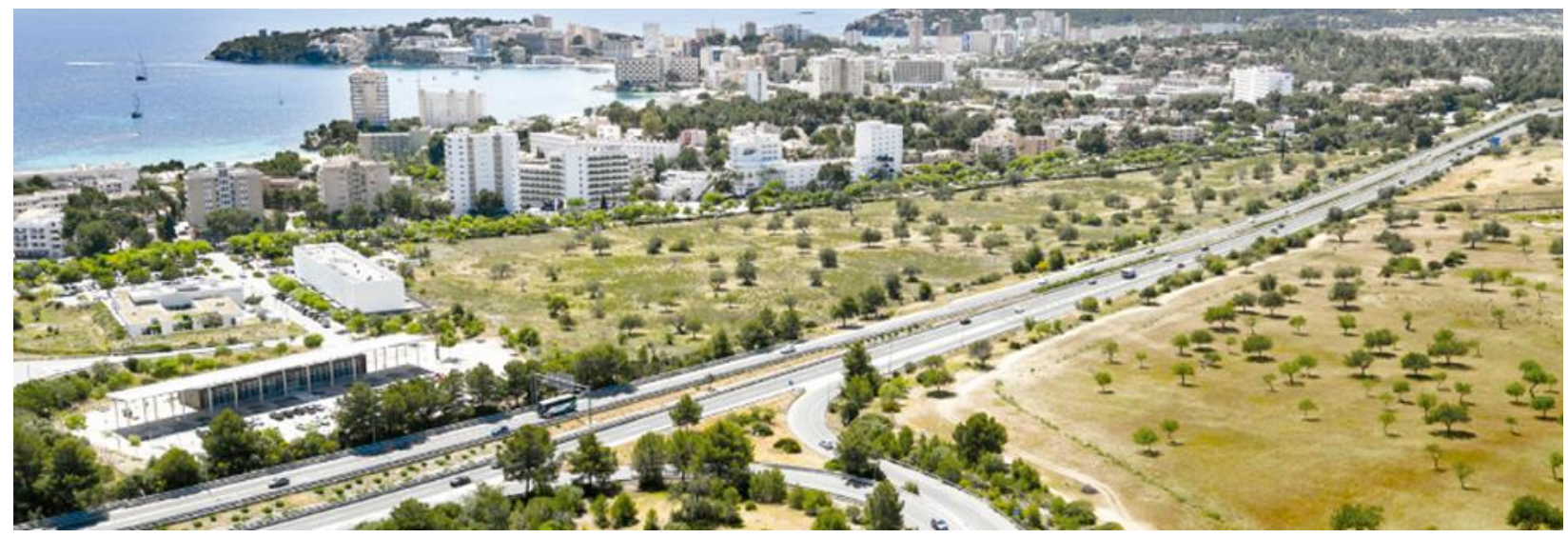

Source: APGOU 2017

Figura 9. Territorial planning. SES Planes Triangle Project

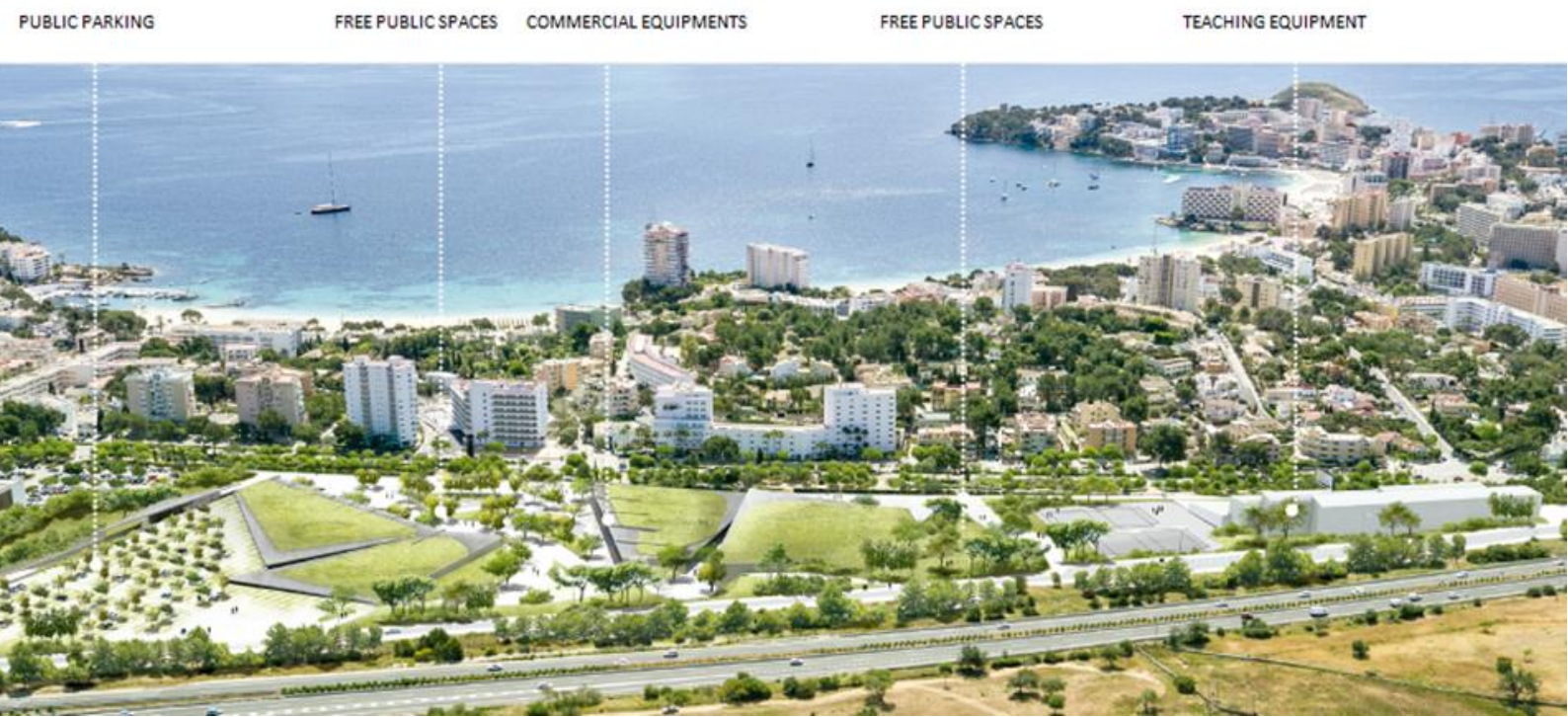

Source: APGOU 2017 
Conclusions:

- The goal of the Agenda Local 21 of a $1348 \mathrm{Ha}$ of developable land reduction was successfully met as we have seen in the maps which compares the situation before and after the PGOU 2000. This objective was properly implemented in the PGOU2000. However, we see how the developable land increases from $19 \mathrm{Ha}$ to 76 $\mathrm{Ha}$ in the modification of the PGOU in 2009 and rise again in the APGOU2017 until $87 \mathrm{Ha}$. The reason of these changes are the actions above described and some other actions the municipality has planned. In general terms, we can conclude that the Agenda 21 goal was achieved, however there has been an evolution of the developable land since the first modification of the PGOU which is not in line with the Agenda 21 principles and it should be considered. A monitoring of the proposals should be done in order to ensure their commitment with the environment is not purely based on the economic development leaving out the Agenda 21 ideals.

- MPGOU 2000 aimed to achieve a comprehensive rehabilitation of the coastal space, but very significant changes have not been made. The municipality has performed small constructions every year in the towns which respond to the necessity of maintenance and renovation of the public spaces, however the great expectations put on the esponjamiento have not been met. The APGOU 2017 recognises that the great buildings of the 60 s of the last century are still there and replacement operations have not come. For this reason, we can affirm that the goal of a comprehensive rehabilitation of the coastal space has not been achieved.

- The current position of the municipality in the APGOU 2017 counters with the spirit of the Agenda 21, which objected the urban development in Calvià as a result of the consequences it brought in the 20th Century. The APGOU 2017 resigns, defending that this development is unstoppable, and the best option is to lead the change. With this argument proposes some actions as the above described. This position can be considered as conformist and it does not fit very well with the ambitious objectives the municipality needs related to the energy transition, water consumption, waste generation and transport. 
- According to the Ecobarri Son Bugadelles, many proposals have been made for years in this area. The most recent one is this residential area which tries to be justified with the argument of considering the environmental impact with the measures above mentioned. However, there is no doubt that this action will create an impact which would not exist if there was not any action. A new residential area will not only affect the land, increasing the surface run-off, but the rise in the population will cause a higher energy and water consumption, waste generation and more overloaded roads. Even if the Municipal Council promises a greater energy efficiency, the promotion of non-motorized modes of transport or the integration of water consumption minimization systems, this construction will cause a high impact in Calvià. When the local government justifies this action with the green measures that will accompany it, it is doing greenwashing.

- In relation to the dry marine of Son Bugadelles, the conclusion is similar to the Ecobarri Son Bugadelles, since the extension of the industrial estate of Son Bugadelles included one only project some years ago and it finally splitted in these two actions. Both areas are adjacent and have similar conditions. Once again, the Municipal Council wrap the project with measures that lower the environmental impact.

- The project of the Natural Park Magaluf marine consists of many actions. In one side, we have the proposal of the new lamination raft. In addition, the Cami de Sa Porrassa will be suppressed, and the wetland recovery and the naturalization of the front sea is planned. This action is very ambitious and would imply a very positive impact in Magaluf. However, it is important to remind that this project is in the advance phase of the APGOU 2017, thus it is still far to be implemented and the project could change. In the other side, other projects accompany this action, and in this case, they follow a different goal of the preservation of the environment. These are the commercial touristic zone, the protected housing and other smaller projects which plan to be carry on.

- Finally, the project of Ses Planes triangle is slightly different to the previous ones, since it proposes to occupy an area which is not used and create a public space where people could enjoy. In the same way as they previous projects, this one will be 
accompanied by measures to lower its environmental impact, but the environmental study of Ses Planes triangle describes the unavoidable consequences it will bring to the territory. To conclude, even if this project will cause an impact in the municipality, it will create an important value to it, will provide the inhabitants with a public space to enjoy and will prevent other less environmentally friendly projects to be performed in the future in this area, so the balance is positive.

\subsection{Transport}

PGOU 2000 already in the year 1999 recognises the deficiencies of the transport in Calvià. It means, only $17 \%$ of the total commutes were made by bus, while $43 \%$ by car. According to the Agenda Local 21 of Calvià, in the year 1995 in the municipality everyday around 70.000 vehicles were driven during the high season and there were around 70 million of commutes every year. 50 million of them corresponded to tourists, it means 2,25 commutes/ person/ day, and the rest to residents with 1,25 commutes/ person/ day and a 95\% of their movements by car. In the year 1998, the municipal motorization index exceeded 900 vehicles per thousand inhabitants, while the regional one the same year was less than 800 . The same data nowadays shows that the trend is the same, in the year 2019 the municipal motorization index was 1.022 vehicles per thousand inhabitants, and the index in the Balearic Islands was 914 (Institut d'Estadística de les Illes Balears, s.f.).

AGENDA LOCAL 21

Goals: Improve public transport and promote pedestrian and bicycle commutes

Initiative: Initiative 29 and initiative 30 of the ERI 
Goal: a more fluid and homogeneous link between the various areas of the municipality

Initiative: incorporation of Passeig Calvià and adaptation of the transversal road axis (C-719 road)

MPGOU 2000 had the objective of a spatial structuring of the municipal territory, by improving its communications network, which guarantees a more fluid and homogeneous link between the various areas of the municipality. In order to meet this goal, there were two guidelines. Firstly, the incorporation of the Passeig Calvià (Calvià promenade); secondly, the adaptation of the transversal road axis (C-719 road) between Palmanova and Peguera.

Regarding the second guideline, the municipality defended the partial utilization of the current trace, splitting the road for $8,55 \mathrm{Km}$. However, as a legal requirement, the Government of the Balearic Islands included its own proposal of an extension of the western highway in the Plan director sectorial de carreteras of CAIB. According to the MPGOU 2000, the municipality has strongly counter against this proposal several times, but these allegations were totally dismissed.

Conclusions:

- In first place, the deficiencies in the public transport criticized in the first paragraph are still a challenge in the present, since the APGOU 2017 identifies as one of its objectives to face this problem, so the situation has not really improved. One of the proposals of the initiative 30 of the ERI, which demands a better Palma-Andratx connection has been partially met with the implementation of the bus line to the university. But it is still far to be successful since the bus is way slower than using the car, so it is not an alternative solution for the students of the municipality to use rather than their own vehicles. This lack of alternatives contributes highly to the car dependence, shown in the municipal motorization index of the year 1998 and 2019, which are compared and demonstrate that it has not gone any better either.

- According to the Agenda 21, the prediction of the regional authorities expanding the road network in order to give solutions to the transport issues of the islands came true with the extension of the western highway, despite the municipal resilience. In 
this case, the municipality tried hard to object the regional government, bringing on the above-mentioned proposals, so it hardly can be criticized.

- Seventeen years later, the Passeig Calvià, is still in progress and is one of the key proposals in the transport agenda of the municipality. It shows the slow performance of the Municipal Council and a lack of innovative initiatives.

\subsection{Energy}

AGENDA 21

Goal: reach the sustainability scenario

Initiative: initiative 32 of the Comprehensive Rehabilitation Scenario or ERI

Our analysis starts in 1995 and our source of information is the Agenda Local 21 of Calvià. According to it, the final energy consumption in the municipality was 31.071 TOE, of which only 70 TOE were renewable energy and produced 257.625 tons/year of $\mathrm{CO}^{2}$ emissions from energy consumption (Prats, 1998). The Agenda Local 21 of Calvià include a hypothesis with three possible scenarios in the year 2015 placed from the worst expected scenario to the best possible one, named risk, stabilization and sustainability scenario and shown in the table 1.

Table 1. Energy future scenarios 


\begin{tabular}{|c|c|c|c|}
\hline & RISK SCENARIO & $\begin{array}{l}\text { STABILIZATION } \\
\text { SCENARIO }\end{array}$ & $\begin{array}{c}\text { SUSTAINABILITY } \\
\text { SCENARIO }\end{array}$ \\
\hline $\begin{array}{l}\text { Energy } \\
\text { consumption }\end{array}$ & $\begin{array}{c}\text { 57,165 TOE / } \\
664,828,950 \mathrm{Kwh}\end{array}$ & $\begin{array}{c}\text { 52,360 TOE / } \\
608,946,800 \mathrm{Kwh}\end{array}$ & $\begin{array}{c}\text { 52,360 TOE / } \\
608,946,800 \mathrm{Kwh}\end{array}$ \\
\hline $\begin{array}{l}\text { Renewable sources } \\
\text { (\%) }\end{array}$ & $\begin{array}{c}401 \text { TOE / 4,663,630 } \\
\text { Kwh } \\
(1 \%)\end{array}$ & $\begin{array}{c}5,071 \mathrm{TOE} / \\
58,975,730 \mathrm{Kwh} \\
(12 \%)\end{array}$ & $\begin{array}{c}\text { 8,891 TOE / } \\
103,402,330 \mathrm{Kwh} \\
(22 \%)\end{array}$ \\
\hline $\begin{array}{l}\mathrm{CO}^{2} \text { emissions } \\
\text { (from energy } \\
\text { consumption) }\end{array}$ & 477,528 tonnes/year & 259,868 tonnes / year & 204,038 tonnes / year \\
\hline
\end{tabular}

Source: Agenda Local 21; Conversion: own elaboration,

The ERI, in its initiative 32 aims to achieve a stabilization-reduction of the energy demand in Calvià.

Table 2 presents the data of the years 1995, 2007, 2014, 2015 and 2018.

Table 2. Energy Data 1995-2018

\begin{tabular}{|c|c|c|c|c|c|}
\hline & 1995 & 2007 & 2014 & 2015 & 2018 \\
\hline $\begin{array}{l}\text { Energy } \\
\text { consumption }\end{array}$ & $\begin{array}{c}31.071 \text { TOE/ } \\
361.355 .730 \\
\text { Kwh }\end{array}$ & $\begin{array}{c}35.764,4 \\
\text { TOE/ } \\
415.940 .091 \\
\text { Kwh }\end{array}$ & $\begin{array}{c}31.925,9 \text { TOE/ } \\
371.298 .656,6 \\
\text { Kwh }\end{array}$ & $\begin{array}{c}32.942,23 \\
\text { TOE / } \\
383.129 .824 \\
\text { Kwh }\end{array}$ & $\begin{array}{c}35.401,49 \\
\text { TOE / } \\
411.719 .374 \\
\text { Kwh }\end{array}$ \\
\hline $\begin{array}{l}\text { Renewable } \\
\text { sources (\%) }\end{array}$ & $\begin{array}{c}70 \text { TOE / } \\
814.100 \mathrm{Kwh} \\
(0.2 \%)\end{array}$ & - & $35.400 \mathrm{Kwh} *$ & $\begin{array}{l}43.020 \\
K w h^{*}\end{array}$ & - \\
\hline
\end{tabular}




\begin{tabular}{|l|c|c|c|c|c|}
\hline $\begin{array}{l}\mathrm{CO}^{2} \text { emissions } \\
\text { (from energy } \\
\text { consumption) }\end{array}$ & $\begin{array}{c}257.625 \\
\text { tonnes / year }\end{array}$ & $\begin{array}{c}384.578,21 \\
\text { tonnes / year }\end{array}$ & $\begin{array}{c}343.302,73 \\
\text { tonnes / year }\end{array}$ & - & - \\
\hline $\begin{array}{l}\text { Population (no } \\
\text { inhabitants) }\end{array}$ & 32.587 & 47.934 & 50.363 & 50.328 & 49.333 \\
\hline
\end{tabular}

${ }^{*}$ Data from the Covenant of Mayors website (European Comission, s.f.)

Source: Agenda Local 21; IBESTAT and CALVIÀ Emisions Report 2013-2014

Comparing both tables, we can get some conclusions. It is necessary to consider the rise in the population from 32.587 in 1995 to 50.328 in 2015 to analyse properly this data. In the first place, according to the energy consumption, the data of the year 2015 and the most recent one of 2018, prove that the outcome has been better than expected even in the best case that is the sustainability scenario. In the year 2015 the energy consumption was 35.401,49 TOE, while the sustainability scenario hoped for 52.360 TOE. Secondly, we had a situation of $2 \%$ renewable energy in the year 1995 according to the Agenda Local 21 and the actual condition is far from both the stabilization and the sustainability scenario, which expected $12 \%$ and $22 \%$ of renewable energy respectively by the year 2015 . The current situation is worse than the initial one, with a lower percentage of renewable energy to the total consumption, and it is closer to the starting point and the risk scenario than the other scenarios. According to the data provided by the municipality in the Covenant of the Mayors website, the total renewable energy in Calvià was 43.020 Kwh in 2015, which is a 0,01\% of the total consumption of the municipality. The Strategy Calvia for the Climate and APGOU 2017 have some proposals to address this issue which will be analysed later.

Finally, we have the $\mathrm{CO}^{2}$ emissions, which have suffered an increase from 257.625 tonnes/year in 1995 to 343.302,73 tonnes/year in 2014. Again, the best possible scenario was not reached, and in this case, it is somewhere in between the risk and the stabilization scenario. 
Goal: $20 \%$ of $\mathrm{CO}^{2}$ emission reduction of the year 2007 by the year 2020

Initiatives: Strategy Calvià for the Climate 2013-2020 and Action Plan for the Sustainable Energy 2013- 2020

The analysis continues with the next important attempt to reduce the $\mathrm{CO}^{2}$ emission by focusing on the energy consumption and renewable energy among others. This is the union of Calvià to the Covenant of Mayors in the year 2011. The Covenant of Mayors, responsible of the Sustainable Energy Action Plan 2010-2020 (SEAP from now on), helps the local authorities to make real the greenhouse gas (GHG) emissions reduction.

The action plan of Calvià municipality has been the Report of emissions in Calvià from 2007 to 2013, the Plan de Acción para la Energía Sostenible de Calvià 2013-2020 (Action Plan for the Sustainable Energy 2013- 2020, PAES from now on) and finally the Estrategia Calvià por el clima 2013-2020 (Strategy Calvià for the Climate 2013-2020) (Rodríguez; Salguero \& Rigo, 2012).

The target of the SEAP was to reach a $20 \%$ of $\mathrm{CO}^{2}$ emission reduction of the year 2007 by the year 2020. The strategy to follow was to finish with the heating oil dependence, to develop new efficiency and renewable energy technologies, the implementation of natural gas and to focus on the action on the tourist sector, which is the sector with the higher $\mathrm{CO}^{2}$ emission. Table 3 shows the inventory of $\mathrm{CO}^{2}$ emissions. 
Table 3. Inventory of $\mathrm{CO}^{2}$ emmisions

\begin{tabular}{|c|c|c|c|c|c|}
\hline & 2007 & 2013 & 2014 & $\begin{array}{l}\text { Dif. 2013- } \\
2014\end{array}$ & $\begin{array}{c}\text { Dif. 2007- } \\
2014\end{array}$ \\
\hline $\begin{array}{l}\text { Energy } \\
\text { consumption }\end{array}$ & $\begin{array}{c}384.578,21 \\
(59,42 \% \text { of the } \\
\text { total) }\end{array}$ & $349.185,08$ & $\begin{array}{c}343.302,73 \\
(66,14 \% \text { of the } \\
\text { total) }\end{array}$ & $-1,713 \%$ & $-10,7 \%$ \\
\hline Natural gas* & $\begin{array}{c}6.715,93(1.03 \% \text { of } \\
\text { the total })\end{array}$ & $7.561,37^{*}$ & $\begin{array}{c}7.643,53^{*} \\
(1,43 \% \text { of the total) }\end{array}$ & $1,09 \%$ & $13,81 \%$ \\
\hline $\begin{array}{l}\text { Liquified } \\
\text { petroleum } \\
\text { gas* }\end{array}$ & $\begin{array}{c}16.301,75 \\
(2,51 \% \text { of the } \\
\text { total) }\end{array}$ & $10.730,45^{*}$ & $\begin{array}{c}10.798,48^{*} \\
(2,08 \% \text { of the total) }\end{array}$ & $0,63 \%$ & $-33,75 \%$ \\
\hline Diesel* $^{*}$ & $\begin{array}{c}113.151,10 \\
(17,48 \% \text { of the } \\
\text { total) }\end{array}$ & $28.838,13^{*}$ & $\begin{array}{c}19.576,05^{\star} \\
(3,77 \% \text { of the total) }\end{array}$ & $-32,12 \%$ & $-82,69 \%$ \\
\hline $\begin{array}{l}\text { Road } \\
\text { transport }\end{array}$ & $\begin{array}{c}126.376,43(19,52 \\
\% \text { of the total) }\end{array}$ & $136.513,65$ & $\begin{array}{c}137.692,78(26,52 \% \\
\text { of the total) }\end{array}$ & $0,85 \%$ & $8,95 \%$ \\
\hline $\begin{array}{l}\text { Waste } \\
\text { management }\end{array}$ & $\begin{array}{c}16.533,73 \\
(2,55 \% \text { of the total) }\end{array}$ & $15.200,36^{*}$ & $\begin{array}{c}13.660^{*} \\
(2,63 \% \text { of the total })\end{array}$ & $-0,83 \%$ & $-11,99 \%$ \\
\hline Tonnes $\mathrm{CO}^{2}$ & $647.140,40$ & $532.843,96$ & $519.028,73$ & $-2,59 \%$ & $-19,8 \%$ \\
\hline
\end{tabular}

*Data not updated, correspond to years 2011 and 2012

Source: Report of emissions in Calvià 2007-2014 in tonnes

Despite the discrepancies between the data of renewable energy provided by the Municipal Council in the Covenant of Mayors website and the Agenda Local 21, according to the former table, the Report of emissions in Calvià from 2007 to 2014 clarifies the outcome of the project, which is the following one:

- There has been an important decrease of diesel and liquified petroleum gas equivalent to $82,69 \%$ and $33,75 \%$ respectively. 
- The power consumption has suffered a decrease of $10,7 \%$ of $\mathrm{CO}^{2}$ emission from the year 2007 to 2014 .

- There has been a decrease of 12\% from 2007 to 2014 in the waste management.

- One negative aspect is the $8.95 \%$ increase of $\mathrm{CO}^{2}$ emissions in the road transport.

- Natural gas has also suffered an increase 13,81\% from 2007 to 2012.

The overall outcome is a reduction of 19,80\% of CO2 emission from 2007 to 2014 in Calvià. Which means did the municipality used to achieve this target?

Some of the most significant actions are explained in the Estrategia Calvià por el clima 20132020 (Strategy Calvià for the Climate). In 2012, year when it was written, the main proposal was the investment in the private sector on natural gas.

APGOU 2017

Goals: extend the deal with the Covenant of the Mayors and $\mathrm{CO}^{2}$ emissions reduction of $40 \%$ by 2030 .

Initiative: deployment of photovoltaic panels in the industrial estate of Son Bugadelles (25 Ha) (Figure 10)

Figure 10. Geographical information of the aptitude for photovoltaic installations

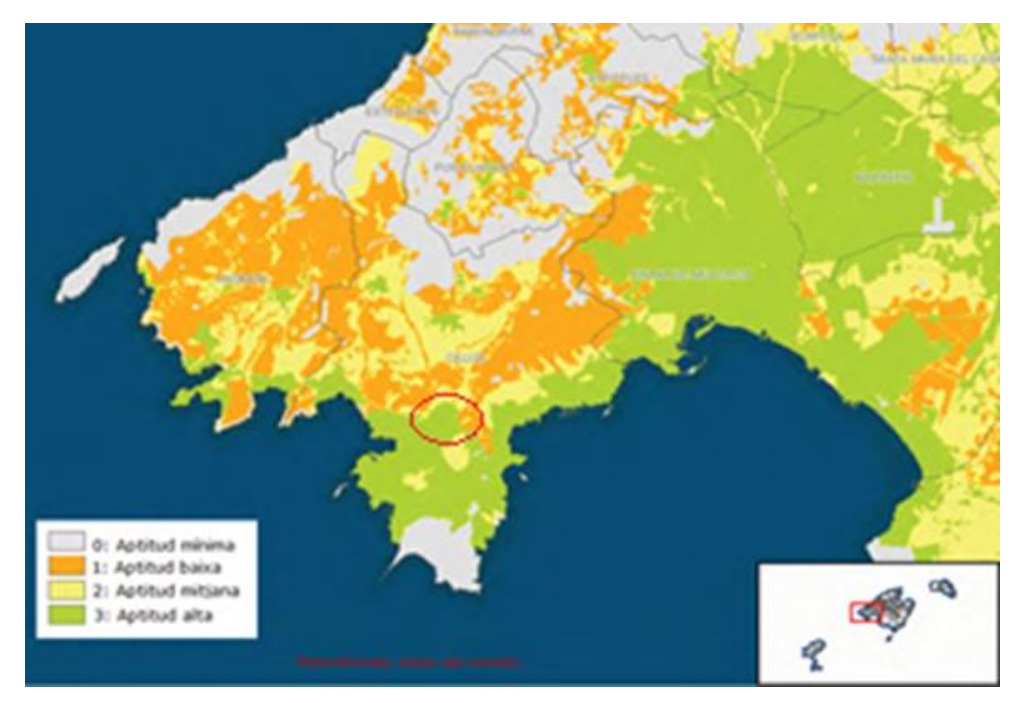

Source: IDEIB, s.f. 
Conclusions:

- According to the first analysis, where the scenarios expected in the Agenda 21 were compared with the actual data, we can summarize that: the energy consumption outcome has been positive based on the expectations, but it is not an actual achievement since it has increased; the renewable energy performance has been very disappointing due to its poor influence in the municipality; and the $\mathrm{CO}^{2}$ emissions have increased, but not that much as expected in the worst possible scenario.

- In relation to the Covenant of Mayors deal, in first place, recognize the achievement of resorting to an international group of experts to meet the municipality goals and to be able to accomplish them. Secondly, there are two aspects to criticize in this agreement. The first critique goes to the goal of $20 \%$ of $\mathrm{CO}^{2}$ emission reduction by 2020. In the Strategy Calvià for the Climate, it was expected a reduction of $15,7 \%$ of the total $\mathrm{CO}^{2}$ emission of the municipality with the only implementation of the natural gas in 2013. It means that the goal was almost met with this only measure seven years before the deadline. This easy reduction gave the municipality the possibility to overlook important issues such as the road transport, which increased its $\mathrm{CO}^{2}$ emission 8,95\% between 2007 and 2014. These arguments demonstrate how low this goal was and how the Municipal Council with a higher commitment could have reached a better outcome. The second critique is toward the "star" measure of the municipality to achieve its goal, the implementation of natural gas. Its main argument was the fast $\mathrm{CO}^{2}$ emission reduction because of the substitution of diesel and liquified petroleum gas by it, which produces $30 \%$ less $\mathrm{CO}^{2}$ emission. This investment was useful to achieve the goal of the Covenant of Mayors; however, it is a short-term measure because it has caused a great investment in natural gas installations which still pollutes. Looking at the objective of a $90 \%$ decrease of $\mathrm{CO}^{2}$ emissions by 2050 of the climate change and energy transition law of the Government of the Balearic Islands, it seems a great mistake the promotion of natural gas rather than renewable energy since now it will be harder to deal with the installations already deployed. Then, some other measures have been proposed such as covering municipal and 
houses roofs with photovoltaic panels in Son Bugadelles, but even if this was achieved, the percentage of renewable energy in Calvià would still be very low.

\subsection{Water}

AGENDA 21

\section{Goals:}

- Reduction of water consumption from 130 and 160 litres/ day per resident and tourist respectively in the year 1997 to 117 and 134 litres/ day per resident and tourist respectively in the year 2007.

- Urban water recycling of $11 \%$ of the total demand by the year 2007.

- Deployment of tertiary systems in all treatment plants of Calvià in less than three years.

Initiative: initiative 31 of the Comprehensive Rehabilitation Scenario or ERI

Agenda Local 21 remarks that in the year 1995 around $10 \mathrm{Hm}^{3}$ of water were consumed. It also exposes that there were losses in the water network of $16 \%$ and the use of own resources were equivalent to a $30 \%$ of the total consumption with a slightly overexploitation of them. By that time, all waste was cleaned up with secondary treatment and $58 \%$ of them were reused mainly to water golf courses. It is strongly criticized in the document the lack of planning oriented to saving and sustainable management of water. 


\section{Goals:}

- Year 2006 (Delgado, 2006):

- Improvement of the purified water quality

- Use of reclaimed water

- Replacement of conflicting sections and elimination of black spots in the networks

- Improvement of the performance of the drinking water network

- Year 2016 (Serra, 2018):

- Deployment of a tertiary system in the new treatment plant of Calvià-Es Capdellà

- The incorporation of a tertiary system to the treatment plant of Santa Ponça which will imply a rise of the regeneration of water from $12 \%$ to an $85 \%$.

Initiative: deployment of a tertiary system in the new treatment plant of Calvià-Es Capdellà and Santa Ponsa

Calvià 2000 S.A is a public company of Calvià municipality responsible of the municipal services according to the area of environmental management and the area of the water cycle since 1987. However, Calvià 2000 S.A does not recognize any significant measure beyond the annual actions to meet goals set, such as reduce losses in the water network. Actually, the objectives year after year keep untouched. Until 2012 there were five treatment plants in Calvià, but then the one of Capdellà was removed (Onieva, 2012).

In the graph 1, we have the volume of water purified in Calvià according to the different treatment plants: 


\section{Figure 11. Purified wáter volumen in Calvià $2018\left(\mathrm{M}^{3} /\right.$ Year $)$}

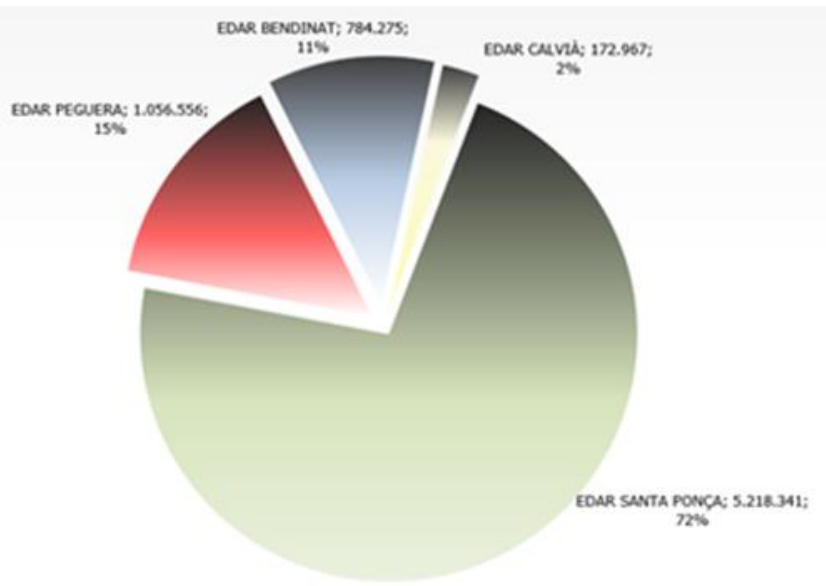

Source: Memoria de gestión Calvià 2000, 2018

PGOU 2017

Goal:

- Relevant objective: implementation of an efficient and comprehensive management of the water cycle

- Secondary objective: guarantee the quality of marine waters and ground and surface waters

- Deployment of tertiary system for all the treatment plants of the municipality

Initiative: development of actions to improve surface runoff and commitment to SUDS (Sustainable drainage systems) measures in urban design, the expansion of the Son Bugadelles treatment plant and the construction of the tertiary system of the Santa Ponça treatment plant

The annual volume of water distributed in the municipality is $10,96 \mathrm{Hm}^{3}$ and the annual volume of water purified according to the different treatment plants is:

- Santa ponsa: $5,8 \mathrm{Hm}^{3} /$ year

- Peguera: $1,28 \mathrm{Hm}^{3} /$ year 
- Bendinat: $0,8 \mathrm{Hm}^{3} /$ year

- Calvià-Es Capdellà: 0,14 Hm³/year

Conclusions:

- In the last annual document of Calvià 2000 SA of 2018, it is still recognised as a challenge to meet the above-mentioned Agenda Local 21 goals. According to the data provided in the APGOU 2017 we see an increase in the water consumption in the municipality from 10 to $10,96 \mathrm{Hm}^{3}$ /year. If we consider the 32.587 inhabitants of the year 1995 with the annual consumption of $10 \mathrm{Hm}^{3}$ and we compare it with the data of 2016, 49.580 inhabitants and 10,96 $\mathrm{Hm}^{3}$ annual water consumption, we get 840,74 $\mathrm{L} /$ person/day in the first case and $605 \mathrm{~L} /$ person/day in the second case. Even if we are not considering the number of tourists, we can clearly conclude that there has been a decrease in the water consumption per person in Calvià.

- According to the other objectives, firstly, the urban recycling water of $11 \%$ by 2007 has been met, but the outcome expected by 2007 is mostly the one of 2018 , a $12 \%$. So, here we see how the objective of the Agenda 21 has been stalled and lacks of renovation. Secondly, the goal of the deployment of tertiary systems in treatment plants is far to be achieved since the only one implemented is in Bendinat. It means only one out of four treatment plants have it. Nevertheless, Calvià 2000 SA plans to implement them in Santa Ponsa and Calvià-Es Capdellà. The APGOU 2017 picks up the former goal with two proposals on the table, however, not enough to meet the goal since does not consider the treatment plant of Paguera.

\subsection{Waste}

AGENDA 21

Goal: reach the Sustainability Scenario and 20, 30 and 70\% separate collection by 2000, 2001 and 2007 respectively

Initiative: initiative 33 of the Comprehensive Rehabilitation Scenario or ERI 
According to data provided by Agenda Local 21 of Calvià, in 1995, the municipality generated around 41,000 Mt of urban waste and 190,000 Mt of rubble and inert waste. This is equivalent to $1.25 \mathrm{~kg}$ per resident per day and $1 \mathrm{Kg}$ per tourist per day. Only $2 \%$ of the total waste previously commented is separate collection. In this same section, efforts to constantly improve cleaning services are criticized, without paying special attention to the separate collection, treatment and recycling of urban waste and rubble. This causes the municipal landfills to fill up, the compost to be lost, and the implementation of nonenvironmentally friendly systems such as the Palma incinerator to be forced.

In the same way as with the energy, the Agenda Local 21, in its section 5, creates three possible scenarios by 2015, which appears in the table 4: Risk Scenario, Stabilization Scenario and Sustainability Scenario.

Table 4. Waste. Future scenarios

\begin{tabular}{|l|l|l|l|}
\hline & \multicolumn{1}{|c|}{ Risk scenario } & \multicolumn{1}{|c|}{$\begin{array}{c}\text { Stabilization } \\
\text { scenario }\end{array}$} & $\begin{array}{c}\text { Sustainability } \\
\text { scenario }\end{array}$ \\
\hline Waste generation & 81.754 tonnes & 76.348 tonnes & 76.348 tonnes \\
\hline $\begin{array}{l}\text { Separate collection } \\
(\%)\end{array}$ & $\begin{array}{l}11.274 \text { tonnes } \\
(13,8 \%)\end{array}$ & 16.140 tonnes $(28 \%)$ & 38.856 tonnes $(75 \%)$ \\
\hline
\end{tabular}

Source: Agenda Local 21

If we compare both tables, we can find some conclusions. Firstly, according to the waste generation, the data of the years 2015 and 2018 prove that the best scenario has not only be achieved, but it has been a success. There has been a rise from 41.339 tonnes to 58.717 tonnes while the Agenda Local 21 expected 76.348 tonnes in the best case. Secondly, we have a different outcome. In this case, the separate collection did not even meet the stabilization scenario. There has been an increase of the percentage of separate collection, from $1,9 \%$ to $24,38 \%$, but a higher improvement was expected. We can say that it was close to reach the stabilization scenario, $28 \%$, but very far from the sustainability scenario, $75 \%$. 
Goal: 10\% waste reduction or 2,5 kg/person/day regarding 2010

Initiative: Plan de Prevención y gestión de residuos (waste prevention and management plan)

Calvià 2000 S.A in 2018 launched its star project in order to achieve the zero waste, this is the Plan de Prevención y gestión de residuos (waste prevention and management plan). In this document, priority is given to the prevention instead of reuse and recycling (Hernández, 2010).

It considers the Ley de residuos y sueloscontaminados (BOE, 2011), which establishes that public administrations must plan prevention measures that will lead them reduce the weight of the residues produced in 2020 in a 10\% respect to the generated in 2010 and according to reuse and recycling establishes a $50 \%$ of recyclable fractions from household waste before 2020. However, in the year 2010 the municipality generated 50.992 tonnes and in 2018, reached 58.717, which means it increased rather than decreased. In the long term, the Ley de residuos y sueloscontaminados de las Illes Balears is taken into account. It defends reducing the waste generation $20 \%$ by 2030 regarding 2010 and increase up to $50 \%$ of the weight for reuse and recycling by 2020 and $65 \%$ by 2030 .

Graph 2 shows the evolution of the waste production per person per day in Calvià, considering not only the local people, but also the tourists which are great contributors to this issue.

Figure 12. Evolution Kg/PAX/Day and waste generation in Calvià 2010-2017 


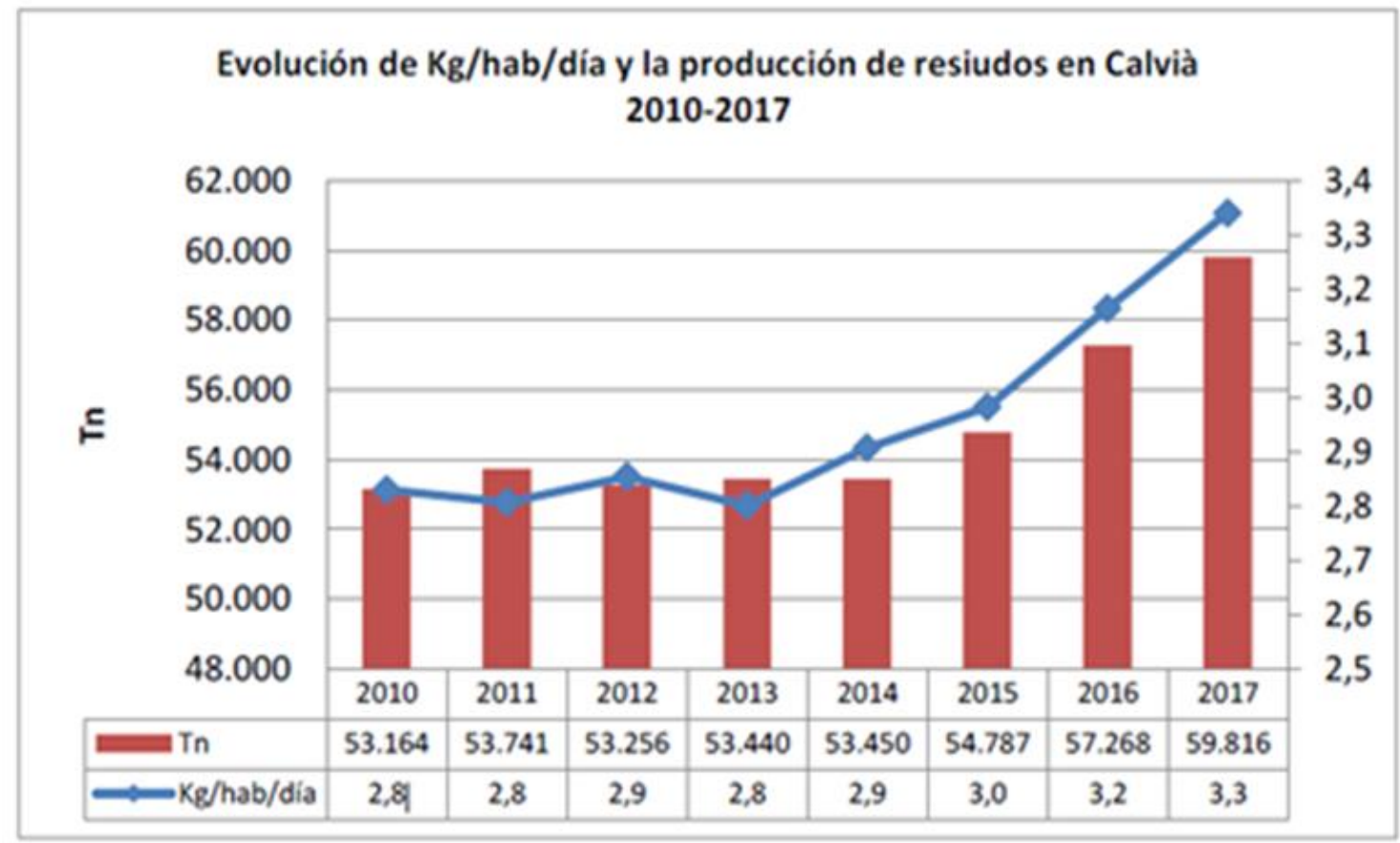

Source: Memoria de gestión Calvià 2000, 2018

The goal above presented of $10 \%$ waste reduction by 2020 is equivalent to a consumption of $2,5 \mathrm{~kg} /$ person/day.

PGOU 2017

Goal: reach zero waste in the municipality

Initiative: delegates to Calvià 2000

In Calvià the following waste facilities are present according to the APGOU 2017:

- In 2002 started to work in Son Bugadelles industrial estate the deixalleria or Green Park.

- There is a 5,700 $\mathrm{m}^{2}$ composting plant belonging to TIRME. The residents of Costa de la Calma complained for years of the bad smells the composting plant releases (Aguiló, 2020).

Conclusions: 
- The Agenda Local 21 proposed two goals. The first one, the waste generation in 2015 was successfully met and the second one according to the separate collection was a failure. However, there are more things to conclude in here. Firstly, the separate collection outcome was really far to the goal and still today is not even close to be achieved. Secondly, what was considered an achievement according to the Agenda 21 it is not for the Plan de Prevención y gestión de residuos. The situation in 1995 was a waste consumption of $1,25 \mathrm{~kg} /$ resident/day and $1 \mathrm{~kg} /$ tourist/day, which is the same as 2,25 kg/person/day. The graph 2 shows a waste production of 3,3 $\mathrm{kg} /$ person/day in Calvià in 2017 and the goal of the Plan is to have a production of $2,5 \mathrm{~kg} /$ person/day. Then, the conclusions seem to be different, what was an achievement for the Agenda 21 is now a failure for the Plan since the situation is worse than 1995.

- Calvià has a composting plant as predicted MPGOU 2000, however it appeared as a solution to manage the waste of Calvià in a responsible way, but it triggered some troubles as we have seen in the APGOU 2017 section.

- The Plan de Prevención y gestión de residuos of Calvià analyses the current situation of the municipality, set concrete goals easy to track and specific initiatives to meet them. For first time Calvià puts all its efforts into the prevention instead of reuse and recycling. It also considers the Ley 22/2011, de 28 de julio, de residuos y suelos contaminados and the Ley de residuos y suelos contaminados de las Illes Balears. It is important to consider that most of the measures depend on people will, which is unpredictable, and it could lead the Plan to the failure. Nevertheless, the good job of Calvià 2000 in the waste management of Calvià must be highlighted.

\section{Comparative study}

\subsection{Urban Agenda for the EU}

As it is described on its own website, the Urban Agenda for the EU was launched in May 2016 with the Pact of Amsterdam and it aims to promote cooperation between ember States, cities, the European Commission and other stakeholders in order to address issues such as the climate change, the energy transition, the circular economy or the urban mobility in the cities of Europe. 
The Urban Agenda for the EU addresses a great variety of issues, but we will analyse the action plans of four of them: The Climate Adaptation Partnership, the Circular Economy, the Energy Transition, and the Partnership for Urban Mobility.

\subsubsection{Climate adaptation partnership}

The main focus of the Climate Adaptation Programme, according to the Working Programme of the Urban Agenda for the EU, is to anticipate the adverse effects of climate change and take appropriate action to prevent or minimise the damage it can cause to Urban Areas. In order to achieve this goal, it proposes concrete actions and the monitoring of its Action Plan.

"A new LIFE for urban adaptation projects" is the most suitable action for the case of Calvià municipality. It is described as an action which aims to improve the access of municipalities and cities to LIFE funding for urban adaptation projects. Four specific problems that prevent local authorities to access LIFE funding for their climate adaptation projects are detected:

- Insufficient co-financing: the 55\% (since 2018) co-financing by LIFE is a barrier for cities since the remaining $45 \%$ is a challenge.

- Complexity: many of the LIFE calls are complex, having timetables and conditions adapted to the different calls.

- Information gaps: local authorities do not always know about LIFE funding.

- Limited support from regional or national authorities: the lack of awareness of these authorities of the LIFE projects submitted by cities and their outcomes can be a barrier.

The technical assistance of LIFE works towards projects which implement environmental or climate action plans on the regional, multiregional or national level to cover several cities.

\subsubsection{Energy transition partnership}


According to its action plan, the Energy Transition Partnership aims to initiate and support a structural change in the way energy systems operate by creating a smarter and more integrated energy system, from a European down to a local level. It focuses on:

- Improving the energy efficiency at a city-level.

- Fostering innovative approaches to energy storage and supply.

- Foster the renewable energy at a local level.

The action that fit the best with the topic analysed in the article is the action 4, "deployment desks for city retrofitting". In the document, the action 4 recognizes the need of retrofitting in most houses to increase their energy efficiency, arguing that around 250 million homes in the EU will need to be retrofitted in order to achieve the energy transition before 2050 and meet the Paris Agreement goals.

The solution proposed is the creation and operation of the called "Deployment Desks", which would work mainly as project development units and providing advice for the municipalities and property owners also. They are public offices, at the local or regional level, whose job is to achieve the regeneration and energy retrofitting. Some of the tasks they could perform are to provide advice on technical solutions, management of public subsidies or help obtaining favourable bank loans to property owners. In order to perform properly their job, they should have to be based in and led by public bodies. It should be considered also the importance of hiring professionals with multiple skills, it means that technical staff should have administrative, legal, social and financial skills in order to have a strong coordination between advice on technical and financial issues.

\subsubsection{Partnership for urban mobility}

The Partnership for Urban Mobility or PUM, as it is said in the Final Action Plan, aims to have a sustainable and efficient urban mobility. The following action has been chosen for its suitability with Calvià municipality issues, by being a potential solution to the problems in transport above described. It is the Action $N^{0} 8$ "Exploring the deployment of New Mobility Services". It shows up proposing New Mobility Services (NMS) as a solution for the congestion, lack of space, toxic air quality and noise caused by the increased population and the overdependence on the private vehicle. In this way, the future of transport sees mobility 
as a combination of services aggregating travel data and communicating with the infrastructure around it. NMS refers normally to new kind of services such as car and bike sharing. The best way to give access to these services is via apps. The great potential of this action is the possibility to reduce car ownership fostering a more rational use of car. If managed properly it could benefit suburban towns where car dependency is high.

\subsubsection{Circular economy}

The Partnership of the Circular Economy has identified some actions which try to go through the existing barriers and also provide advice to cities in order to develop a circular economy. The goal is that inhabitants and entrepreneurs think in terms of resources with a permanent economic and social value rather than in terms of waste.

A key action that the Action Plan of the Circular Economy proposes is develop a "Pay-asyou-throw" toolkit or PAYT. The problem it addresses is the shift from a linear consumptionbased model to a more services-oriented model, where the value is in the product as such and not in the ownership of it. The way to reach it is by fiscal and financial stimuli. Local governments can increase the price of least favoured options or reduce the price of most favoured ones as shown bellow.

\section{Figure 13. The mechanism of financial incentives for a circular economy}

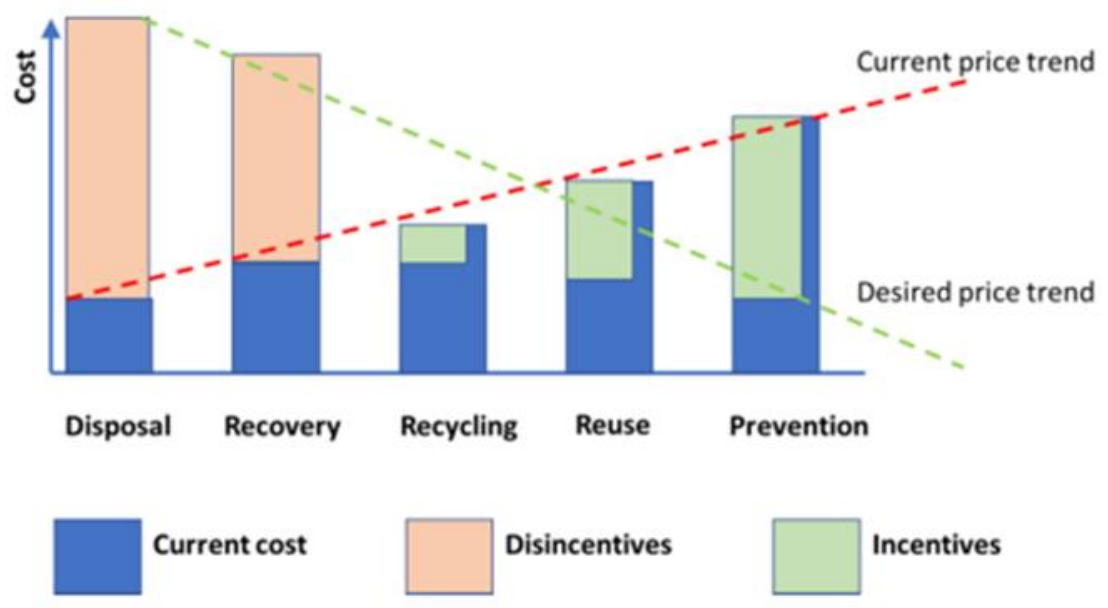

Source: Action Plan of the Circular Economy of the Urban Agenda for the EU 
In figure 13 we can see the way to incentivise recycling, reuse and prevention using taxes, levies and subsidies. PAYT is under the jurisdiction of the municipality and it consists on making the citizens pay a fee according to the amount of waste they produce.

\subsection{Two cases of commitment}

The Clean Energy for EU islands initiative aims to solve the issue that many islands in the EU depend on fossil fuel imports for their energy supply. It helps these islands to create an Agenda which is a roadmap for the transition process towards clean energy. This Agenda designed by local community and adapted to the situation of the island, considers the stakeholders and proposes initiatives and goals. We will get to know two cases: La Palma and Culatra Island.

\subsubsection{La Palma}

The vision of La Palma is: "La Palma is a 100\% renewable island thanks to a combination of clean technologies, energy storage and auto-consumption. Energy efficiency, demand reduction and sustainable mobility are the core of the energy transition".

La Palma is an island of the Canary Islands, in Spain, with a population of 82.000 inhabitants. In 2017 it was able to produce a 10\% of renewable energy of the total energy produced in the island. In 2015, a citizen platform started the process towards a new energy model, which conclude in a manifesto. In response to the citizens' initiative, the parties of the island created the Plan Insular por una Nueva Cultura Energética (Insular Plan for a New Energy Culture or PINCE) which gathered the demands of the manifesto. In order to meet the goals, La Palma joined the Clean Energy for the EU islands project of the European Commission.

In 2019, it developed the first version of the Clean Energy Transition Agenda which is the roadmap to clean energy. The Agenda set the goals and the actions, and it was complemented by an online tool called ClimateView, which will help to ensure the transparency and participation of the stakeholders. This platform shows the updated greenhouse gas emission data of a certain area and classify them per sectors. We can see how it works in figure 14: 


\section{Figure 14. Example of climateview}

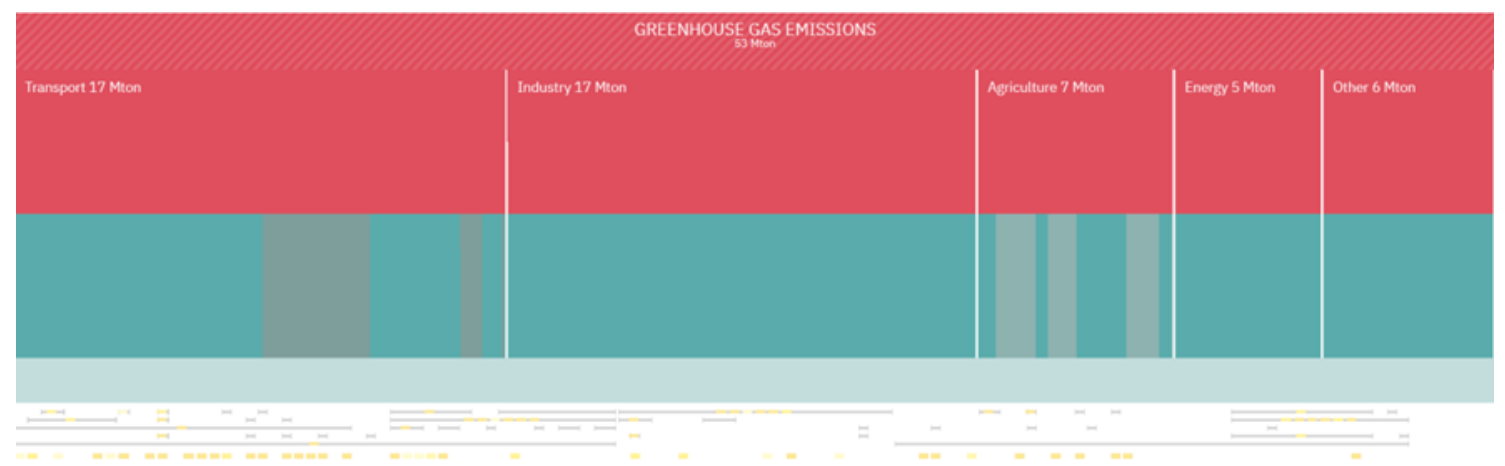

Source: Clean energy transition Agenda of La Palma

The most significant part of the Clean Energy Transition Agenda is that it has always considered the stakeholders participation and the strategies and proposals are made by the citizens and the communities. The most recent outcome is the availability of the tool ClimateView in the island.

\subsubsection{Culatra}

The vision of Culatra is: "The vision of Culatra 2030 Initiative is to: create an energy community that manages and shares its own energy, before 2030, renewable energy will allow for a fully decarbonised electricity system; treat and value its waste; and produce fresh water for self-consumption".

Culatra island belongs to Faro municipality, in Portugal, and has around 1000 inhabitants. The island does not produce renewable energy at all, however $54,1 \%$ of the energy consumed is renewable since it comes from the mainland. The municipality joined the Covenant of Mayors in 2011, as well as Calvià, committing to the same goals. However, it goes further joining the Clean Energy for the EU islands, which provides an additional opportunity to develop and implement a Clean Energy Agenda for Culatra Island. In the Agenda, it is recognized how the cooperation with Clean Energy for EU Islands Secretariat and other European regulatory authorities is essential for the operation of clean energy systems in the islands. 
Some objectives and actions proposed are the following:

Table 5. Objectives and actions proposed

\begin{tabular}{|l|l|}
\hline \multicolumn{1}{|c|}{ Objectives } & \multicolumn{1}{c|}{ Actions } \\
\hline Decarbonise the island's transport & $\begin{array}{l}\text { Design with SunConcept a boat/solar platform by finding } \\
\text { funding at regional, national and European level }\end{array}$ \\
\hline $\begin{array}{l}\text { Increase the energy efficiency and } \\
\text { energy generation capability of } \\
\text { buildings. }\end{array}$ & Creation of the Green Sustainable Culatra2030 Fund \\
\hline $\begin{array}{l}\text { Produce water for self-consumption } \\
\text { Use island sustainability as a pillar } \\
\text { for transition. }\end{array}$ & $\begin{array}{l}\text { Dimension and operate a scalable desalination water plant. } \\
\text { attributed to entities that demonstrate positive behaviours } \\
\text { related to the use of plastic }\end{array}$ \\
\hline
\end{tabular}

Source: Own elaboration

\section{Discussion}

In this section, it will be discussed in the first place the goals Calvià has set in the last twenty years and they will be compared with the ones proposed outside of the municipality. Secondly, the implementation of the proposals made in the comparative study will be considered.

Firstly, we will have a look into the goals that the Government of the Balearic Islands, the United Nations and the Alliance for Climate Emergency and we will discuss whether Calvià is close or not to meet them.

- Firstly, the Ley de cambio climático y transición energética of the Government of the Balearic Islands, proposes a greenhouse gas emission reduction of $40 \%$ and $90 \%$ by 2030 and 2050 respectively and renewable energy consumption of 35\% and 100\% by 2030 and 2050 respectively. 
- Secondly, the United Nations proposes with the Sustainable Development Goals a 45\% CO2 reduction before 2030 and zero emissions by 2050 and by 2030 increase substantially the share of renewable energy in the global energy mix (United Nations, s.f.).

- Finally, the Alliance for Climate Emergency, composed by NGOs such as Greenpeace, Extinction Rebellion, Fridays for Future Mallorca and the GOB, sets the goals the Municipal Councils of the Balearic Islands should sign in order to make effective the Climate Emergency Declaration. These are: 65\% greenhouse gas emission reduction by 2030 regarding 1990 and zero emissions by 2040 and get rid of fossil fuels and use renewable energy as soon as possible. In addition, this group proposes not authorizing more developable land and the clearance of the developable land not performed; not allowing more road infrastructures; zero waste; and reduction in energy consumption among other proposals (Alliance for Climate Emergency, s.f.).

The Agenda Local 21 aimed to have in the best possible scenario 52.360 TOE of energy consumption by 2015, while in 1995 the energy consumption was 31.071 TOE (this mean an increase of $68.5 \%) ; 22 \%$ of renewable energy by 2015 , while in 1995 there was a $0.2 \%$; and 204.038 tonnes/year $\mathrm{CO}^{2}$ emission reduction, while in 1995 the municipality emitted 257.625 tonnes/year (it is a decrease of 26.26\%). Here we see how the record of Calvià is not very in line with the goals above mentioned. Then the municipality set the goal of a $20 \%$ $\mathrm{CO}^{2}$ emission reduction of 2007 by 2020 in the Covenant of Mayors. And most recently, Calvià establishes a new goal with the Covenant of Mayors of $40 \% \mathrm{CO}^{2}$ emission decrease by 2030.In the APGOU 2017 the municipality sticks together with the Sustainable Development Goals and the Ley de cambio climático y transición energética. However, here it is demonstrated how the goals are different to the ones proposed by the United Nations. Furthermore, even if the same goal is set with the Government of the Balearic Island according to the $\mathrm{CO}^{2}$ emission, in the results section the evidences shown question the chance to reach it, for instance, the great investment in natural gas infrastructure which implied a high $\mathrm{CO}^{2}$ emission decrease to certain extent, but in the long term is not useful to meet more ambitious objectives. Finally, the municipality has not joined the goals of the Alliance for Climate Emergency and some of the practices demanded are being violated, 
such as the restrictions related to the developable land, with projects like the Ecobarri and dry marine Son Bugadelles, the Natural Park Magaluf marine and Ses Planes triangle.

In the second place, the comparative study has brought some tools, proposals and examples which if properly implemented in Calvià could lead to a positive change.

Firstly, the Urban Agenda for the EU offers its collaboration to local authorities to meet the Pact of Amsterdam goals. We have seen some actions which could be applicable to certain issues the municipality is facing:

- "A new LIFE for urban adaptation projects": in the results of the article, we have seen the involvement of the municipality in several environmental initiatives related to territorial planning, transport and resources. Probably, Calvià would have done it better with a higher budget. We have seen how one of the most ambitious projects of the Agenda Local 21, the esponjamiento, was not successfully met as a result of the it high cost. This action aims to foster this kind of projects by providing a fund for urban áreas.

- "Deployment Desk": the municipality has put great efforts into the energy efficiency, with the Strategy Calvià for the Climate, for example, in that shows its commitment. However, great projects are planned such as the Ecobarri Son Bugadelles, Ses Planes triangle or the constructions in the Magaluf marine together with the need of retrofitting of great part of the municipality houses which contributes to the high energy consumption of Calvià. For this reason, implementing Deployment Desks which provide expertise advice could lead to a more efficient municipality.

- "Exploring the deployment of New Mobility Services": Calvià struggles with its deficiencies in transport since the Agenda Local 21 and the problems are still the same as twenty years ago: lack of a good public transport network, high motorization index and lack of alternative means of transport. This absence of innovative proposals could be addressed by the NMS proposed in this action, which aims to reduce the overdependence on the private vehicle, improve the connectivity and decrease pollution caused by transport.

- "Pay-as-you-throw": in the waste management section, we have seen how the great failure of the Agenda Local 21 was the separate collection. This action could 
complement the Plan de Prevención y gestión de residuos of Calvià 2000 S.A, giving the municipality the chance to incentivise recycling, reuse and prevention by implementing fiscal and financial stimuli.

Secondly, the two cases presented are examples of two islands with similar conditions to the Calvià municipality, which have adopted the Clean Energy for the EU initiative and have set ambitious objectives. The goal is that they serve as an inspiration and model to follow to Calvià. We could highlight of each of them:

- La Palma: it sets the vision of a $100 \%$ renewable energy and starts to create the Agenda to meet this goal. One of the principles of the Agenda is the community and stakeholder's participation, which helps to the commitment of the different parts with it. A key action has been the implementation of the ClimateView tool, in order to promote transparency and participation. In Calvià, the lack of renewable energy is an issue, we have already seen it in the energy consumption section. La Palma situation is similar; however, it has set a strategy to address it in a different way, and Calvià could use benchmarking (Cernat \& Gourdon, 2011).

- Culatra2: it aims to produce its own energy by using renewable energy, treat its waste and produce water for self-consumption. The current situation of the island is far from its goals; however, many initiatives are on the table. The Clean Energy Agenda for Culatra Island sets concrete objectives and actions. Some of these actions are quite innovatives and Calvià could consider the possibility to study their implementation. Here again, Calvià could use benchmarking with Culatra.

\section{Final conclusions}

In the present document, we have analysed the evolution of Calvia by sectors, studying the most significant initiatives and drawing some individual conclusions of them and we have

\footnotetext{
${ }^{2}$ Sustainable tourism benchmarking tool (STBT): The objective of the STBT is two-fold. Firstly, this methodology should be able to detect the sustainability problems in a tourism destination. Secondly, using benchmarks and policy-relevant indicators, the methodology should enable policymakers to make informed decisions and improve the prospects for sustainable tourism development in their countries. (Cernat L., 2011)
} 
also gone over a comparative study, in which some interesting proposals, which could be implemented in the municipality, have been described.

The research done has sought an answer to the research questions asked at the beginning. The set of the conclusions reached in every section of the article puts together an answer considering every aspect studied.

- Is there an actual commitment of the municipal council to the environment? And if it is the case, is it doing its best?

We have seen how Calvià is putting great efforts to create a more sustainable municipality and it shows its awareness, however in order to conclude if there is an actual commitment or not, different aspects should be considered. According to the territorial planning, the political action has redirected the route that was leading the municipality to the collapse in the 20th Century. However, many of the proposed objectives have not been reached such as the proposal of a comprehensive rehabilitation of the coastal space and the current projects of urban development which counter with the Agenda 21 goal of the developable land reduction. In addition, the municipality is not performing ambitious projects such as the attempt of esponjamiento or any other new proposals which are missing. As a result of that, we can conclude that even if there is a commitment in this point, the optimal scenario has not been achieved. In relation to the transport, we are currently struggling with the same issues than twenty years ago such as the deficiencies in the public transport and the car dependency, while the multiplication of the road network is still a fact. There is also a lack of innovative proposals since the key project of the municipality is still the Passeig Calvià. In this case, the municipality can not be considered to be committed with the cause and it is far to do its best. In general, Calvià is more energy efficient than before as demonstrated in the previous analysis mainly at expense of the implementation of the natural gas and some good initiatives has been performed being the Covenant of Mayors the most significant one. However, the goals set in this area are quite low and far to reach the zero emissions and the energy self-sufficiency, focusing mainly in the $20 \%$ of $\mathrm{CO}^{2}$ emission reduction by 2020 .

Then, the commitment can not be denied, but clearly, it is not doing it best. Our outcome of the water management proves that the data of water consumption are slightly better since the water consumption per person is lower today than twenty years ago, but some of the 
goals have not been met, for instance, the one of the deployment of tertiary systems in treatment plants in Calvià. Some other objectives have been stalled like the urban recycling water of $11 \%$ by 2007 , which in 2018 was a $12 \%$. Here we have again the case of commitment with the objectives, but not even close to the best possible scenario. Finally, there is the waste management, in which despite the current situation in some cases is better than the one expected, for example reaching the sustainability scenario according to the waste generation, the great deficiencies such as the separate collection shadow the successes that this sector could had. Therefore, considering the recent Plan de Prevención y gestión de residuosof Calvià 2000 S.A, even if the management could have been much better, we trust in the engagement of the municipality to create a positive impact in the following years.

- Where should it head from now on?

Based on the conclusions we had of the results of the municipality management in its different sectors and the comparative study we did afterwards, we can get some ideas. We have concluded that there is an actual commitment of the municipality with the environment in most of the sectors. However, the issues that are being faced, are not easily solved. Most of the time, the same initiatives are proposed year after year due to the lack of innovative proposals. We have also seen how the Covenant of Mayors brought Calvià clear goals and a helped for the elaboration of an Action Plan. These two statements empower the idea that Calvià should join an international group of expertise. The Urban Agenda for the EU could be a good option. It would complement the work the municipality is already doing by setting ambitious goals, providing new tools such as the ones previously explained, helping to create a roadmap and ensuring its achievement by monitoring its performance. Finally, cooperation with other municipalities is necessary. The establishment of a network where transparency prevails and the different municipalities can benefit from each other information by using benchmarking, could help to face similar issues. Here is where the cases of La Palma and Culatra could serve as an example for Calvià.

To put it in a nutshell, considering the municipality has shown commitment to the environment in many cases, it has not met every objective even taking into account some of them were quite low, it is not leading to the best possible scenario due to it' s not setting 
the most ambitious goals and some good practices such as the ones shown in the comparative study are being ignored, we will grade Calvià municipality with a 6 out of 10 .

\section{Bibliographic References}

Alliance for Climate Emergency (s.f.). Moció Emergència Climàtica. Retrieved from the group of Greenpeace Mallorca on https://greenwire.greenpeace.es/ on May 12 ${ }^{\text {th }}, 2020$.

Ajuntament de Calvià. Desenvolupament històric urbanístic. Retrieved from http://www.calvia.com/ ("PGOU revisió section) on May 12th 2020

BOE. Ley 22/2011, de 28 de julio, de residuos y suelos contaminados. Retrieved from https://www.boe.es/ on May 12th 2020.

BOE. Ley 8/2012, de 19 de julio, del Turismo de las Illes Balears. Retrieved from https://www.boe.es/ on May 12 ${ }^{\text {th }}, 2020$.

BOE. Llei 10/2019, de 22 de febrer, de canvi climàtic i transició energètica. Retrievev from https://www.boe.es/ on May 12 ${ }^{\text {th }}, 2020$.

Dañobeitia, J. D. (2000). Plan General de Ordenación Urbana de Calvià. Memoria. Retrieved from Calvià Town Hall.

Dañobeitia, J. D. (2006). Modificaciones puntuales del PGOU 2000. Retrieved from http://www.calvia.com/ on May $12^{\text {th }}, 2020$.

Delgado, C. (2006). Memoria de gestión Calvià 2000. Retrieved from https://www.calvia2000.es/ (Memòries de Gestió section) on May 12 ${ }^{\text {th }}, 2020$.

European Commission. Circular Economy. Action Plan. (2018). Retrieved from https://ec.europa.eu/futurium/en/circular-economy on May 12 ${ }^{\text {th }}, 2020$

European Commission. Climate Adaptation Partnership. Final Action Plan. (2018). Retrieved from https://ec.europa.eu/futurium/en/climate-adaptation on May $12^{\text {th }}, 2020$

European Commission. Partnership for Urban Mobility. Final Action Plan. (2018). Retrieved from https://ec.europa.eu/futurium/en/urban-mobility on May 12 ${ }^{\text {th }}, 2020$. 
European Commission. Agenda para la Transición a la Energía Limpia. La Palma. (2019). Retrieved from https://euislands.eu/document/clean-energy-transition-agenda-lapalmaon May $12^{\text {th }}, 2020$.

European Commission. Clean Energy Transition Agenda. Culatra Island, Portugal. (2019). Retrieved from https://euislands.eu/document/clean-energy-transition-agenda-culatra on May $12^{\text {th }}, 2020$

European Commission. Energy Transition Partnership. Action Plan. (2019). Retrieved from https://ec.europa.eu/futurium/en/energy-transition on May $12^{\text {th }}, 2020$.

European Commission. Covenant of Mayors for Climate \& Energy. (s.f.). Retrieved from https://www.covenantofmayors.eu/ (Calvià- Progress section) on May 12 ${ }^{\text {th }}, 2020$

Prats, F. (1997). Agenda Local 21 Calvià. Retrieved from Calvià Town Hall

Prats, F. (1998). Agenda Local 21 Calvià. Escenario de Rehabilitación Integral. Retrieved from Calvià Town Hall

García, S. (2017). Documento de avance para la revisión del Plan General. Documento Inicial Estratégico. Retrieved from http://www.calvia.com/ (Ciutadania-Pla General de Ordenació Urbana section) on May $12^{\text {th }}, 2020$.

Hernández, V. M. (2010). Memoria de gestión Calvià 2000. Retrieved from https://www.calvia2000.es/ (Memòries de Gestió section) on May 12 ${ }^{\text {th }}, 2020$.

Institut d'Estadística de les Illes Balears. Retrieved from https://ibestat.caib.es/ on May $12^{\text {th }}$, 2020.

Infraestructura de Dades Espacials de les Illes Balears (IDEIB). Retrieved from https://ideib.caib.es/on May 12th, 2020.

Cernat, L., \& Gourdon, J. Paths to Success: Benchmarking Cross-Country Sustainable Tourism (2011). Retrieved from https://doi.org/10.1016/j.tourman.2011.12.007 on $15^{\text {th }}$ de octubre de 2021.

Onieva, M. (2012). Memoria de gestión Calvià 2000. Retrieved from https://www.calvia2000.es/ (Memòries de Gestió section) on May 12 ${ }^{\text {th }}, 2020$. 
Barcik, R. (s.f). Research Strategy: Case Study. Business lecturer. Retrieved from https://www.youtube.com/watch?v=ectS1ote8uA\#Types on May 12 ${ }^{\text {th }}, 2020$.

Rodríguez, A., Salguero, J., \& Rigo, S. (2012). PAES. Estrategia Calvià por el Clima 20132020. Retrieved from https://www.covenantofmayors.eu/ (Calvià- Action Plan section) on May $12^{\text {th }}, 2020$.

Serra, A. (2018). Memoria de gestión Calvià 2000.Retrieved from https://www.calvia2000.es/ (Memòries de Gestió section) on May 12 ${ }^{\text {th }}, 2020$.

United Nations. United Nations Development Programme. Retrieved from https://www.undp.org/ on May $12^{\text {th }}, 2020$. 